Portland State University

PDXScholar

$2-1-2020$

\title{
Neotectonic and Paleoseismic Analysis of the Northwest Extent of Holocene Surface Deformation along the Meers Fault, Oklahoma
}

Kristofer Tyler Hornsby

Portland State University, kristoferhornsby@gmail.com

Ashley R. Streig

Portland State University, streig@pdx.edu

Scott E.K. Bennett

U.S. Geological Survey

Jefferson Chang

Sarkeys Energy Center

Shannon Mahan

U.S. Geological Survey

Follow this and additional works at: https://pdxscholar.library.pdx.edu/geology_fac

Let us know how access to this document benefits you.

\section{Citation Details}

Hornsby, K. T., Streig, A. R., Bennett, S. E., Chang, J. C., \& Mahan, S. (2020). Neotectonic and Paleoseismic Analysis of the Northwest Extent of Holocene Surface Deformation along the Meers Fault, Oklahoma. Bulletin of the Seismological Society of America, 110(1), 49-66.

This Article is brought to you for free and open access. It has been accepted for inclusion in Geology Faculty Publications and Presentations by an authorized administrator of PDXScholar. Please contact us if we can make this document more accessible: pdxscholar@pdx.edu. 


\title{
Neotectonic and Paleoseismic Analysis of the Northwest Extent of Holocene Surface Deformation along the Meers Fault, Oklahoma
}

\author{
Kristofer T. Hornsby ${ }^{1,2}$, Ashley R. Streig ${ }^{* 1}$, Scott E. K. Bennett ${ }^{3}$, Jefferson C. Chang ${ }^{4,5}$, and Shannon Mahan ${ }^{6}$
}

\begin{abstract}
The Meers fault (Oklahoma) is one of few seismogenic structures with evidence for Holocene surface rupture in the stable continental region of North America. The 37-kilometer-long southeast section of the full 54-kilometer-long Meers fault is interpreted to be Holocene active. The 17-kilometer-long northwest section is considered Quaternary active, but not Holocene active. We reevaluate surface expression and earthquake timing of the northwest Meers fault to improve seismic source characterization. We use airborne light detection and ranging and historical stereopaired aerial photos to evaluate the fault scarp and local faultzone geomorphology. In the northwest, complex surface deformation includes fault splays, subtle monoclinal warping, and a minor change in fault strike. We interpret that the alongstrike transition from surface faulting on the southeast Meers fault to surface folding on the northwest Meers fault occurs at the lithologic contact between Permian Post Oak conglomerate and Hennessey shale. We excavated a paleoseismic trench to evaluate the timing of surface-deforming earthquakes on the northwest section of the fault. The excavation revealed weathered Permian Hennessey shale and an 1-2-meter-thick veneer of Holocene alluvial deposits that were progressively deformed during two surface-folding earthquakes likely related to blind fault rupture beneath the site. Repeated onlapping to overlapping stratigraphic sequences and associated unconformities are intimately related to folding events along the monocline. OxCal paleoearthquake age modeling indicates that earthquakes occurred 4704-3109 yr B.P. and 5955-4744 yr B.P., and that part of the northwest section of the Meers fault is Holocene active. We find the Holocene-active section of the Meers fault should be lengthened $6.1 \mathrm{~km}$ to the northwest, to a total Holocene-active fault length of $\mathbf{4 3} \mathrm{km}$. Empirical scaling relationships between surface rupture length and magnitude reveal that the fault could generate an $\boldsymbol{M}_{\mathrm{w}} \mathbf{7 . 0}$ earthquake.
\end{abstract}

\section{KEY POINTS}

- This study reevaluates surface expression and earthquake timing along the northwest Meers fault.

- Repeated onlapping to overlapping sequences and unconformities are related to folding events along the fault.

- The mapped Holocene-active Meers fault should be lengthened $6.1 \mathrm{~km}$ to the northwest, to a total $43 \mathrm{~km}$ length.

Supplemental Material

\section{INTRODUCTION}

The 54-kilometer-long Meers fault in southwestern Oklahoma is the only fault in Oklahoma with evidence for Holocene surface displacement. Published maps distinguish two collinear sections of the Meers fault (Fig. 1): the southeast 37-kilometerlong section is well defined, subvertical, and Holocene active (Madole, 1988; Crone and Luza, 1990; Kelson and Swan, 1990;
Swan et al., 1993; Jones-Cecil, 1995), and the northwest 17kilometer-long section, which has not been mapped in detail, lacks paleoseismic age constraints, and has only discontinuous evidence for recent, surface-deforming earthquakes due to its subdued surface expression (Wheeler and Crone, 2001). Splays of the Meers fault northwest of the Holocene scarp are apparent in magnetic data (Jones-Cecil, 1995), and coincide with the northwest trace.

1. Portland State University, Portland, Oregon, U.S.A.; 2. Now at BGC Engineering, Golden, Colorado, U.S.A.; 3. U.S. Geological Survey, Menlo Park, California, U.S.A.; 4. Oklahoma Geological Survey, Sarkeys Energy Center, Norman, Oklahoma, U.S.A.; 5. Now at USGS Hawaii Volcano Observatory, Hawaii National Park, Hawaii, U.S.A.; 6. U.S. Geological Survey, Denver, Colorado, U.S.A

*Corresponding author: Streig@pdx.edu

Cite this article as Hornsby, K. T., A. R. Streig, S. E. K. Bennett, J. C. Chang, and S. Mahan (2019). Neotectonic and Paleoseismic Analysis of the Northwest Extent of Holocene Surface Deformation along the Meers Fault, Oklahoma, Bull. Seismol. Soc. Am. 110, 49-66, doi: 10.1785/0120180148

(c) Seismological Society of America 
This study evaluates geomorphic expression and earthquake timing of the northwest Meers fault through new detailed mapping on light detection and ranging (lidar)-derived highresolution topography and a paleoseismic excavation. We document lithologic controls on the style of surface deformation and map a monoclinal fold scarp along the southeastern $6.1 \mathrm{~km}$ of the northwest section of the Meers fault. A paleoseismic trench along this section revealed weathered Permian Hennessey shale, an 1-2-meter-thick veneer of Holocene alluvial deposits and evidence of at least two surface-deforming earthquakes in the form of monoclinal fold scarps paired with unconformities and related onlapping stratigraphic sequences. Accelerator Mass Spectrometry (AMS) radiocarbon (RC) dating and optically stimulated luminescence (OSL) age dating constrain stratigraphic ages of deformed Holocene deposits, and are used to generate preferred and alternate OxCal age models for site stratigraphy and earthquakes. These data are used to revise the Holocene-active surface rupture length (SRL) and the timing of surface-deforming earthquakes on the Meers fault.

This study is part of a larger effort to improve Holocene fault length and earthquake recurrence for seismic source characterization of the Meers fault by generating the first detailed fault maps on high-resolution topography coupled with paleoseismic trenches to evaluate paleoearthquake timing and recurrence (Streig and Chang, 2018). Two paleoseismic sites were located on the southeast section of the Meers fault (Streig and Chang, 2018), and one paleoseismic excavation on the northwest section is presented here. Results of this northwest Meers fault study will improve probabilistic seismic hazard analysis in the central and eastern United States (CEUS). We present a workflow that is appropriate for fault activity evaluations of subtle topographic scarps, particularly fold scarps in weak lithologies. Systematic application of mapping incorporating fault perpendicular topographic profiles combined with paleoseismology may be appropriate for other intraplate faults that form monoclinal folds, including the New Madrid fault zone in the CEUS.

\section{GEOLOGIC SETTING}

Southwest Oklahoma is host to the southern Oklahoma aulacogen, a failed Precambrian rift zone, which trends west-northwest and includes the Wichita Mountains, the Anadarko and Hardeman basins, and the Wichita Frontal fault system (Gilbert, 1983a). During the Pennsylvanian to early Permian, structural inversion of the southern Oklahoma aulacogen occurred as regional compressional stresses formed the thrust-bounded Wichita uplift (Perry, 1989). Reverse faulting, uplift, and syntectonic foreland sedimentation resulted from the collision of Gondwana and the southern continental margin of late Paleozoic North America (Perry, 1989; Baker and Holland, 2013). Pre-existing crustal weaknesses that formed during Precambrian to Cambrian rifting were reactivated as reverse or thrust faults in this compressional to transpressional stress regime (Perry, 1989; Hanson et al., 2013). The Wichita Frontal fault system forms the boundary between the WichitaAmarillo uplift to the southwest and the Anadarko-Ardmore sedimentary basin to the northeast. The Meers fault is the only known Holocene-active fault in the Wichita Frontal fault system (Gilbert, 1983a,b; Luza et al., 1987; Madole, 1988), and its $\mathrm{N} 60^{\circ} \mathrm{W}$ strike and subvertical dip is suboptimally oriented for left-lateral slip in the modern horizontal compressive stress regime, which trends $\sim \mathrm{N} 85^{\circ} \mathrm{E}$ (Holland, 2013; Darold and Holland, 2015). The Criner fault is located southeast along strike, and has been considered a possible southeastern continuation of the Meers fault (Fig. 1). Tectonic geomorphic and structural studies of the Criner fault reveal a southwest-facing fault scarp and find that the fault does not displace Quaternary sediments (Briggs et al., 2008). The escarpment is an erosional bedrock fault-line scarp, and displaces Late Pennsylvanian bedrock (Walker, 2006; Briggs et al., 2008).

The Meers fault is geomorphically prominent and linearly traverses topography along the southeast section (Figs. 1 and 2 ), indicating that the fault plane must be near vertical (Crone and Luza, 1990; Jones-Cecil, 1995). Although the Meers fault lacks historical seismicity (Baker and Holland, 2013), the escarpment exhibits a prominent down-on-the-southwest geomorphic expression and offsets Holocene deposits (Madole, 1988; Crone and Luza, 1990; Kelson and Swan, 1990). The Meers fault left-laterally deflects stream channels indicating that late Quaternary slip rates exceed erosion or denudation rates (Kelson and Swan, 1990). Along its length, the fault cuts two Permian bedrock units at the surface, the Post Oak conglomerate and the Hennessey shale (Fig. 2c; Crone and Luza, 1990). The Post Oak conglomerate in the study area is a well-indurated, limestone-pebble conglomerate in a limestone matrix, and is relatively resistant, forming prominent southwest-facing bedrock scarps where cut by the Meers fault. The Hennessey shale is less-resistant and forms low-relief, rounded fault scarps where cut by the Meers fault.

\section{PREVIOUS MAPPING OF THE MEERS FAULT}

The southeast section of the Meers fault is distinct in aerial imagery (Fig. S1, available in the supplemental material to this article). Surface deformation was first mapped as a 26-kilometer-long linear escarpment with down-on-the-southwest vertical displacement by Gilbert (1983b). Holocene geomorphic expression was lengthened to $37 \mathrm{~km}$ using low-sun aerial photographic mapping (Ramelli and Slemmons, 1990). Cetin (1991) proposed lengthening the Holocene active fault an additional $17 \mathrm{~km}$ to the northwest (Fig. 1). Evidence for Holocene activity along the northwest Meers fault is based on geomorphic mapping of offset fluvial terraces, deflected drainages, and stream bank exposures of bedrock and alluvium with apparent vertical separation on trend with the southeast main trace of the fault (Cetin, 1991). Because of a lack of quantitative age results from offset stratigraphy, this $17 \mathrm{~km}$ section lacked convincing 


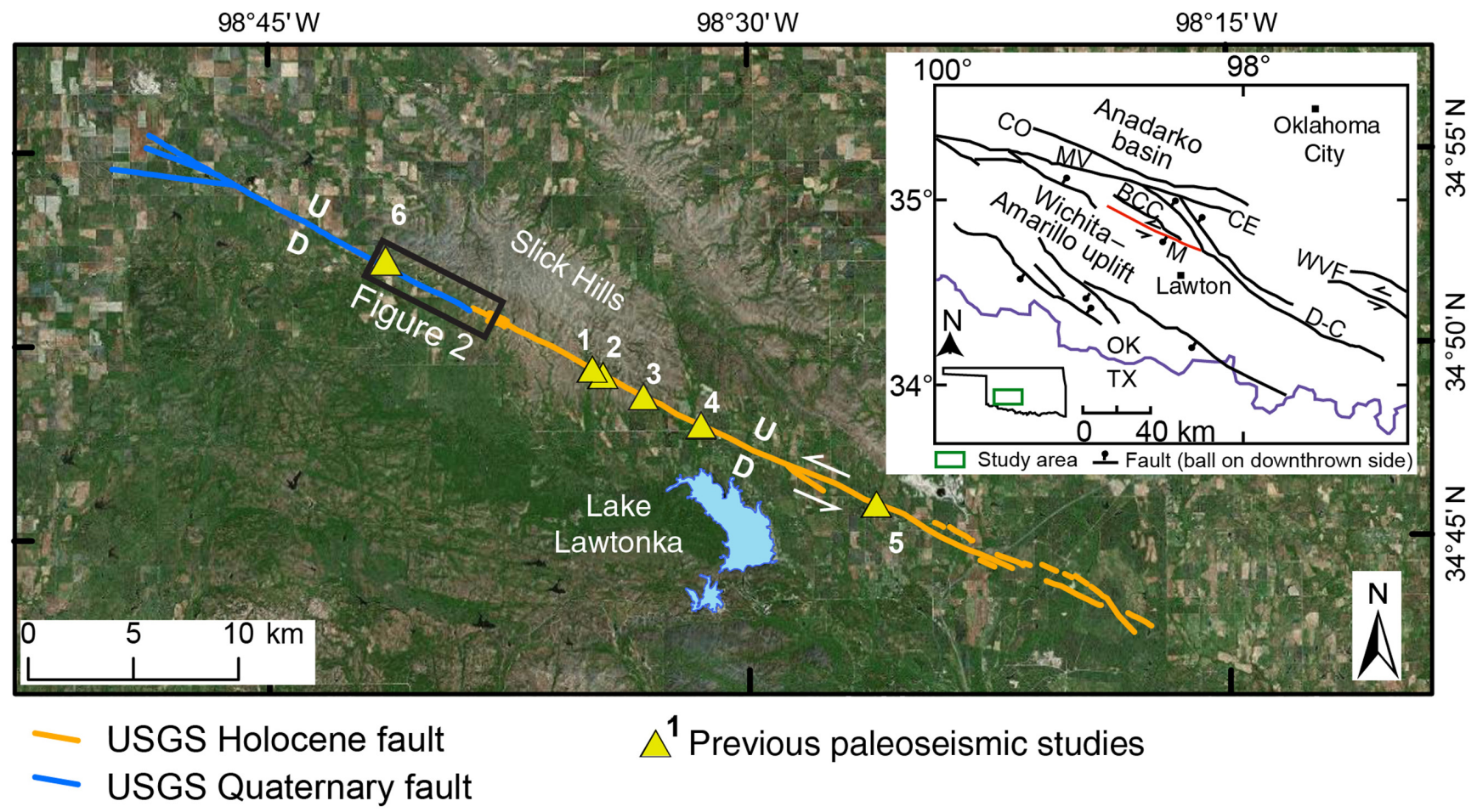

evidence of Holocene surface-rupturing earthquakes (Crone and Wheeler, 2000; Wheeler and Crone, 2001). This section is mapped as Quaternary active, not Holocene active in the Quaternary fault and fold database (Fig. 1; Crone and Wheeler, 2000; U.S. Geological Survey [USGS], 2006).

\section{PREVIOUS PALEOSEISMIC INVESTIGATIONS OF THE MEERS FAULT}

Madole (1988) conducted the first tectonic geomorphic study on the Meers fault at the Canyon Creek and Browns Valley sites along the southeast fault section (Fig. 1). He concluded that the most recent surface-deforming earthquake occurred between $\sim 1400$ and 1100 yr B.P., and that folding accounted for at least as much vertical displacement as brittle faulting (Madole, 1988). Crone and Luza (1990) excavated two trenches at the Canyon Creek site where the fault deforms weathered Hennessey shale (Fig. 1) east of the Slick Hills. Crone and Luza (1990) document brittle faulting and fissures within alluvial units, and document broad monoclinal warping as the primary style of surface deformation. They concluded that the average surface-deforming event on the fault typically generates $1.5-2 \mathrm{~m}$ (maximum of $3 \mathrm{~m}$ ) of dip slip and 3-5 $\mathrm{m}$ of lateral slip. They found that deformation is primarily a result of "plastic" deformation in the Hennessey shale, thus making lateral movement difficult to quantify (Crone and Luza, 1990). Using empirical relationships between SRL and magnitude, Crone and Luza (1990) found that the Meers fault may be capable of generating an $M_{\mathrm{w}} \sim 7.0$ earthquake. Based on their average net displacement results as well as the absence of a major escarpment, they inferred that the fault may be characterized by a long recurrence interval with temporal clustering in the late Holocene.
Figure 1. Overview map of the Meers fault in southwest Oklahoma, faults from the U.S. Geological Survey (USGS) Quaternary fault and fold database (see Data and Resources, USGS, 2006; based on original mapping by Crone and Wheeler, 2000). Solid lines represent the currently mapped Holoceneactive trace of the fault, and dashed lines represent the Quaternary (preHolocene) fault traces (see Data and Resources, USGS, 2006). The black rectangle outlines the study area. Triangles shown here and used in subsequent figures are locations of paleoseismic studies conducted in the late 1980s through early 1990s; 1, valley site (Kelson and Swan, 1990); 2, northwestern ponded alluvium (PA) site (Kelson and Swan, 1990); 3, PA and southeastern PA sites (Crone and Luza, 1990; Kelson and Swan, 1990); 4, Canyon Creek site (Luza et al., 1987; Madole, 1988; Crone and Luza, 1990); 5, Browns Creek site (Madole, 1988); 6, Saddle Mountain Creek sites (Cetin, 1991). Figure modified from Streig and Chang (2018). (Inset) Regional faults in southwest Oklahoma along the Wichita-Amarillo uplift. Black lines are major bedrock faults with pre-Quaternary activity. Inset modified from Crone and Luza (1990). BCC, Blue Creek Canyon fault; CE, Cement fault; CO, Cordell fault; D, downthrown side; D-C, Duncan Criner fault; M, Meers fault shown in the overview map; MV, Mountain View fault; $\mathrm{U}$, upthrown side; WVF, Washita Valley fault. The color version of this figure is available only in the electronic edition.

Kelson and Swan (1990) excavated paleoseismic trenches at the valley site, northwestern ponded-alluvium site, and ponded-alluvium site, located northwest of the Canyon Creek site along the southeast section of the Meers fault (Fig. 1). The authors documented evidence of two surface-rupturing earthquakes in the last $\sim 3400 \mathrm{yr}$ along the Meers fault (Fig. 1). They inferred that the penultimate event occurred between $\sim 2900$ and $3400 \mathrm{yr}$ B.P., and that the most recent earthquake (MRE) ruptured $\sim 1050$ yr B.P. (Kelson and Swan, 1990; Swan et al., 1993). They also concluded that surface deformation is accommodated by both brittle faulting and folding, and that the style 
(a)

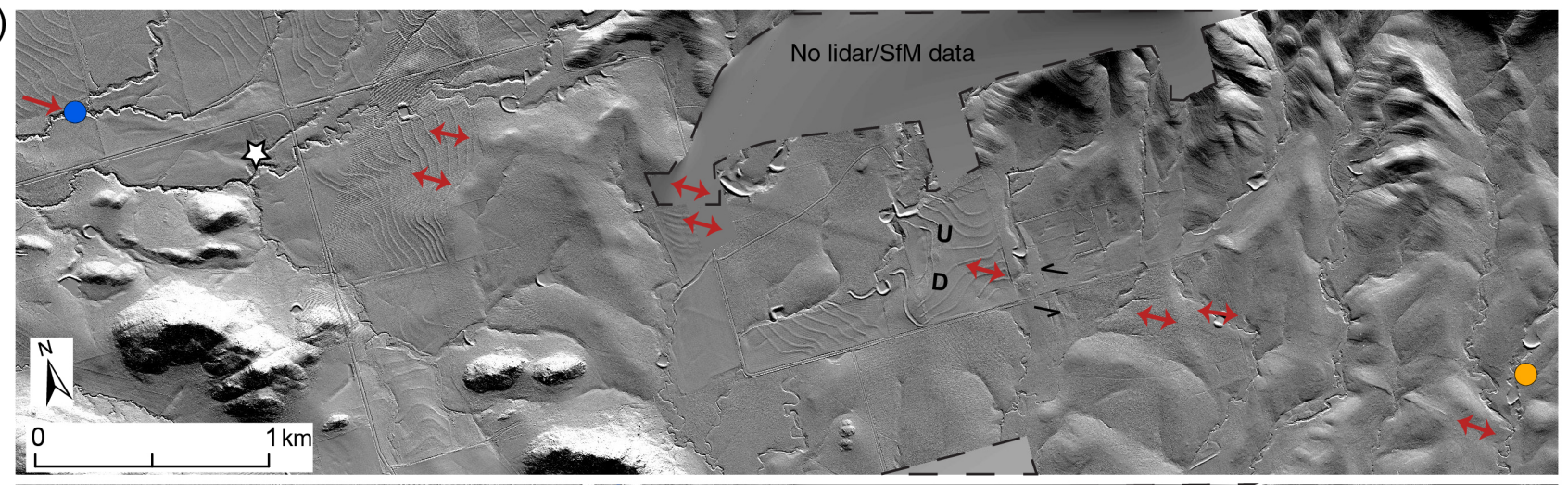

(b)

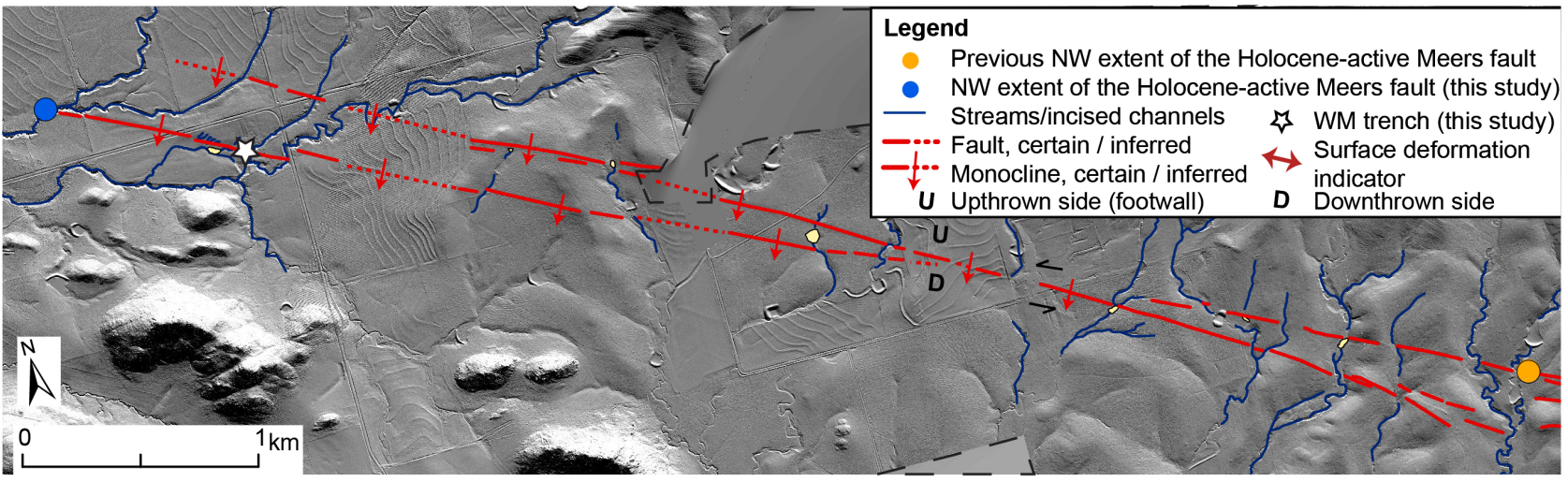

(c)

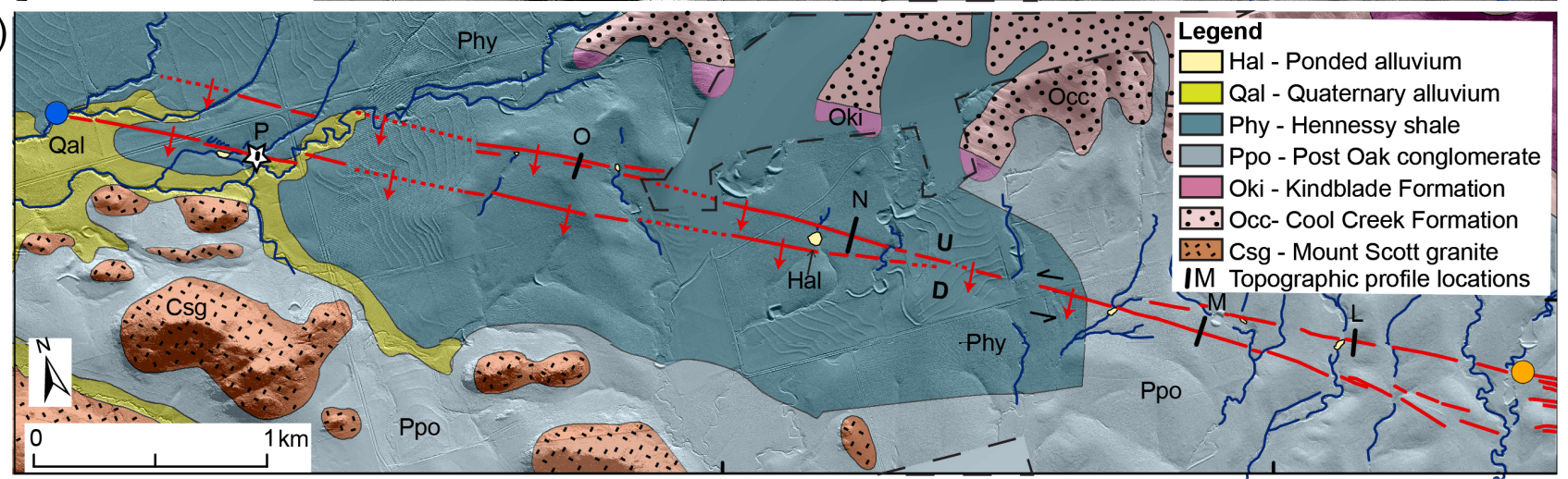

of deformation varies greatly along fault length. Kelson and Swan (1990) also excavated trenches parallel to the fault at the northwest ponded-alluvium and ponded-alluvium sites (Fig. 1) and identified offset buried channels north and south of the fault. The buried channel deposits were used as piercing points to estimate left-lateral displacements, which ranged from $3.0 \pm$ $1.1 \mathrm{~m}$ to $3.7 \pm 1 \mathrm{~m}$ (Kelson and Swan, 1990; Swan et al., 1993). Published paleoseismic studies and technical reports have documented left-lateral reverse slip as the mode of surface deformation on the southeast section of the fault, with lateralto vertical-slip ratios ranging from 1.3:1 (Kelson and Swan, 1990; Swan et al., 1993) to 5:1 (Crone and Luza, 1990). Using buried thalwegs from multiple trenches as piercing points, Swan et al. (1993) estimated that the average net slip per event along the southeast trace of the fault ranges from 1.75 to $3 \mathrm{~m}$ and the maximum net displacement ranges from 3.5 to $5.25 \mathrm{~m}$.
Figure 2. Light detection and ranging (lidar)-derived hillshade maps of the northwest section of the Meers fault. The light circle on the east margin of the image is the previously mapped northwest extent of the Holocene-active Meers fault (shown in Fig. 1) and the dark circle on the west margin is the revised northwest Holocene-active extent (this study). (a) Arrows are fault parallel and highlight breaks in slope along the fault. (b) Fault strip map, lines are mapped fault and fold scarps (this study). Closed depressions infilled with ponded alluvium are mapped as small, light polygons along the downthrown (southwestern) side of the fault. Incised drainages shown as solid lines generally perpendicular to the fault. (c) Geologic map shows major lithologies, modified from 1:100,000-scale Lawton quadrangle geologic map (Stanley and Miller, 2005). Bedrock units important to this study include the Post Oak conglomerate (Ppo), and Hennessey shale (Phy). A subset of topographic profiles (lettered $L-P$ ) are shown as black bars across the fault; see Figure 4a for location map of all topographic profiles along the Meers fault from this study. SfM, structure from motion; WM, Water Moccasin. The color version of this figure is available only in the electronic edition. 


\section{METHODS}

\section{Fault scarp morphology mapping}

We used high-resolution topographic data to map geomorphic features along the northwest Meers fault. Lidar data analyzed during this study was collected by the Natural Resources Conservation Service in 2009 and 2013, the USGS in 2013, and the Federal Emergency Management Agency in 2015 (see Data and Resources). We interpolated the point cloud data into 1 and $3 \mathrm{~m}$ resolution digital elevation models (DEMs). From the DEMs, we generated several derivative products, including hillshade, slope, aspect, and curvature maps to enhance subtle topographic variations in the landscape and to identify and interpret tectonic-related geomorphic features such as escarpments, linear ridges, closed depressions, deflected drainages, and variations in channel incision across the fault zone.

We extracted 18 topographic profiles perpendicular to the fault to estimate separation of the ground surface $(H)$, vertical separation (V.S.), and scarp width $(W)$ along the southeasternmost $\sim 40 \mathrm{~km}$ of the 54-kilometer-long Meers fault, following the conventions of Caskey (1995). To examine subtle fault scarp morphology, we supplemented the lidar data with structure from motion (SfM) generated high-resolution topographic data from weather balloon-based photographs at seven key locations along the northwest section of the fault (see Fig. S2). These balloon-based SfM point clouds have a lower point density than the lidar data and tend to capture more topographic signatures from vegetation and are not bare-earth models. We applied a $0.1 \mathrm{~m}^{2}$ grid to the SfM point cloud data and included only the lowest elevation point within each grid cell to reduce noise from the grassland vegetation.

The landscape along the northwest Meers fault has been locally anthropogenically altered, largely from agricultural practices. We analyzed aerial photographs from 1942 to visualize fault geomorphology prior to modification. We mapped fault-related topography visible in these stereopair images using a 3D tabletop stereoscope. We also mosaiced these overlapping images into an orthophoto using Agisoft PhotoScan software. We field-checked geomorphic features that were initially identified using lidar, balloon-based photogrammetry, and historical aerial photos.

\section{Paleoseismic trenching}

We conducted paleoseismic trenching to determine the timing of scarp-forming earthquakes along the northwest Meers fault. We selected the Water Moccasin (WM) paleoseismic trench location based on a combination of lidar mapping, topographic profiles, and field observations, which allowed us to identify a site along the northwest Meers fault with little anthropogenic disturbance and a high potential for fine-grained overbank Holocene alluvial deposition. The slot trench was $21 \mathrm{~m}$ long, excavated perpendicular to the fault scarp $\left(\mathrm{N} 25^{\circ} \mathrm{E}\right)$ using a rubber-tire backhoe with a 24-inch-wide bucket. A 6-meter-long dogleg slot trench, oriented $\mathrm{N} 76^{\circ} \mathrm{E}$, was also excavated to capture any potential northwest-striking fault splays that were observed in the adjacent irrigation ditch. We installed a nail grid $\left(1 \mathrm{~m}^{2}\right)$ on the trench walls to map stratigraphic relationships and faultrelated deformation in a local coordinate system. We photographed the trench walls and mosaiced the images using Agisoft Photoscan software to create high-resolution orthomosaics, following the trench wall photomosaic workflow of Reitman et al. (2015). For each trench wall, we mapped the stratigraphic and structural contacts between geologic units directly on large printouts (trench logs) of the high-resolution trench orthomosaics.

We collected samples from several geologic units exposed in the trench walls for age dating. We examined trench walls for visible macro-organic material, which was limited to detrital charcoal. We described, photographed, and mapped the location of each detrital charcoal sample in the field. Visible organic material was rare in the trench walls, so we collected bulk sediment samples from each mapped trench unit to further search for microfossils and microcharcoal in the lab. Bulk samples were added to deionized water and put into an ultrasonic cleaner for sonication to separate and float charred organic material. Macrocharcoal and microcharcoal were reviewed and photographed under a binocular microscope to describe sample size and charcoal morphology. We submitted six macrocharocal samples to Beta Analytic for ${ }^{14} \mathrm{C}$ AMS dating. After sample processing, only one sample yielded a sufficient mass for ${ }^{14} \mathrm{C}$ dating (Table 1). We sent five bulk samples that lacked visible organic material to PaleoResearch Institute for further analysis for microcharcoal extraction, three of these yielded sufficient microcharcoal material for ${ }^{14} \mathrm{C}$ AMS RC dating (Table 1). Because of the low abundance of detrital charcoal visible in the trench, we also collected two OSL samples from sandy deposits and analyzed these samples at the USGS Luminescence Dating Laboratory (Table 2).

We developed an OxCal Bayesian statistical age model (Bronk Ramsey, 2009) for the site that only incorporates the $\mathrm{RC}$ age results to create an earthquake age model. OSL age results were not in agreement with the RC results and suggested that the grains may have undergone partial bleaching (e.g., Gray et al., 2015). We used the minimum OSL age values with the $\mathrm{RC}$ ages in an alternate OxCal age model.

\section{RESULTS AND INTERPRETATIONS}

\section{Northwest Meers fault morphology}

Analysis of lidar, balloon-based SfM datasets, and historical aerial photos allowed us to document tectonic geomorphic features along the southern $6.1 \mathrm{~km}$ of the northwest section of the Meers fault (Fig. 2), and we found no discernable tectonic geomorphic features farther to the northwest. Topographic expression of the northwest Meers fault is subtle yet forms relatively continuous $\mathrm{N} 60^{\circ} \mathrm{W}$-striking southwest-facing scarps. We observe increased incision of ephemeral streams on the upthrown (northeastern) side of the scarp, as well as locally ponded alluvium at the base of the escarpment, immediately southwest of the fault 
TABLE 1

Accelerator Mass Spectrometry Radiocarbon (RC) Age Results from the Water Moccasin (WM) Trench, Meers Fault, Oklahoma

\begin{tabular}{|c|c|c|c|c|c|c|c|}
\hline WM-16-RC15 & Beta-449221 & $2930 \pm 30$ & -23.6 & $3167-2974$ & $1 c$ & 1.52 & Macrocharcoa \\
\hline WM-16 & PRI-5545 & $5229 \pm 25$ & -22.77 & $6170-5919$ & $3 b$ & 2.82 & Microcharcoal \\
\hline WM-9 & PRI-5705 & $8609 \pm 40$ & -22.67 & 9672-9524 & 4 & 1.63 & Microcharcoal \\
\hline
\end{tabular}

*Samples are listed in stratigraphic order. Locations are shown in Figure 7 and Figure S4, available in the supplemental material to this article.

'Initial sample preparation and selection were done at Portland State University. RC samples were prepared and separated at PaleoResearch Institute, Inc. (PRI), Beta Analytic, Inc., and the National Ocean Sciences Accelerator Mass Spectrometry facility.

*The reported age is in RC years using the Libby half-life of $5568 \mathrm{yr}$ and following the conventions of Stuiver and Polach (1977); uncertainty shown is $\pm 1 \sigma$. RCYBP is the RC years before present age prior to calibration to the ${ }^{14} \mathrm{C}$ curve.

(Fig. 2c). At some locations, the fault scarp is more easily distinguished as a tonal lineament in our 1942 aerial photograph orthomosaic (Fig. S1) than in modern lidar and balloon-based SfM data (e.g., Fig. 2a), because the twenty-first-century lidar datasets postdate widespread agricultural alteration of the landscape. Evidence of lateral displacement such as deflected drainages and offset terrace deposits along the northwest section of the fault was not detectable from the background sinuosity of the drainages.

\section{Along-strike patterns of vertical separation}

Our analysis of fault-perpendicular topographic profiles highlights along-strike differences in the magnitude of vertical separation (Figs. 3 and 4b). Down-on-the-southwest separation of the ground surface is apparent in the profiles along the entire fault (Fig. 3; Table S1). We find clear geomorphic evidence of a break in slope on trend with the mapped trace of the Meers fault on the southern $6.1 \mathrm{~km}$ of the northwest section (Figs. 3 and $4 \mathrm{~b}$ ). No scarp was observed farther to the northwest along the mapped Quaternary trace of the fault (Figs. 3 and 4b). Along the northwest section of the Meers fault, the scarp is characterized by decimeter-scale vertical separations that are much smaller than vertical separations on the southeast section of the fault (Fig. 4b). Here, the fault traverses both Post Oak conglomerate and Hennessey shale bedrock, and vertical separation at the transition from one lithology to the other is broadly consistent (Fig. 4). In the Post Oak conglomerate, we find a maximum vertical separation of $1.5 \mathrm{~m}$ and minimum $0.6 \mathrm{~m}$, and in the Hennessey shale we observe maximum vertical separation of $0.6 \mathrm{~m}$ and minimum vertical separation of $0.2 \mathrm{~m}$ (Fig. 4).

The largest vertical separations are along the southeast Meers fault and tapers both to the northwest and southeast (Fig. 4b). Here, fault scarps in Post Oak conglomerate exhibit vertical separations of as much as $5.6 \mathrm{~m}$, and scarps in the Hennessey shale exhibits vertical separations as high as $2.2 \mathrm{~m}$ (Fig. 4).

TABLE 2

Quartz Optically Stimulated Luminescence Age Results from the Water Moccasin (WM) Trench, Meers Fault, Oklahoma

\begin{tabular}{|c|c|c|c|c|c|c|c|c|c|c|c|}
\hline WM-16-L01 & $4(20)$ & $0.39 \pm 0.03$ & $2.88 \pm 0.19$ & $3.00 \pm 0.32$ & $1.29 \pm 0.07$ & $\begin{array}{l}9.23 \pm 0.59 \\
29.4 \pm 2.7\end{array}$ & $\begin{array}{l}3(48) \\
45(48)\end{array}$ & $\begin{array}{l}62 \% \\
62 \%\end{array}$ & $2 f$ & $\begin{array}{l}7,160 \pm 1,200 \\
22,790 \pm 4,880\end{array}$ & $\begin{array}{l}\text { Minimum } \\
\text { age } \\
\text { Central } \\
\text { age }\end{array}$ \\
\hline WM-16-L02 & $2(17)$ & $0.37 \pm 0.03$ & $2.22 \pm 0.16$ & $2.50 \pm 0.23$ & $1.25 \pm 0.07$ & $\begin{array}{l}7.03 \pm 0.45 \\
13.9 \pm 1.4\end{array}$ & $\begin{array}{l}4(36) \\
33(36)\end{array}$ & $\begin{array}{l}54 \% \\
54 \%\end{array}$ & $2 a$ & $\begin{array}{l}5,620 \pm 580 \\
11,120 \pm 2,520\end{array}$ & $\begin{array}{l}\text { Minimum } \\
\text { age } \\
\text { Central } \\
\text { age }\end{array}$ \\
\hline
\end{tabular}

Samples run at U.S. Geological Survey Luminescence Dating Laboratory (Denver, Colorado).

*Field moisture, with figures in parentheses indicating the complete sample saturation $\%$. Dose rates calculated using $25 \%$ of the saturated moisture (i.e., $4(48)=48 \times 0.25=12)$ except for WM-16-L2 where a 75\% water moisture was used as this unit was almost completely beneath the water table.

${ }^{\dagger}$ Analyses obtained using high-resolution gamma spectrometry (high purity Ge detector).

FIncludes cosmic doses and attenuation with depth calculated using the methods of Prescott and Hutton (1994). Cosmic dose rates were 0.16-0.20 Gy/ka.

$\S$ Number of replicated equivalent dose $\left(D_{E}\right)$ estimates used to calculate the equivalent dose. Figures in parentheses indicate total number of measurements included in calculating the represented $D_{E}$ and age using the minimum age model; analyzed via single aliquot regeneration on quartz grains.

"Defined as "overdispersion" of the $D_{E}$ values. Values $>30 \%$ are considered to be poorly bleached or mixed sediments.

\#Dose rate and age for fine-grained 250-290 $\mu \mathrm{m}$ size quartz. Exponential + linear fit used on equivalent dose, errors to $2 \sigma$ on age all others are one sigma. 



Figure 3. Topographic profiles measured perpendicular to the fault scarp. Locations are shown in Figures $2 \mathrm{c}$ and $4 \mathrm{a}$. Bedrock unit and lithology at each profile location shown above upper right corner of each plot. From left to right, profile directions are oriented southwest to northeast. Representative measurements of fault characteristics are shown in gray on profile B. For each profile, V.S. is vertical separation of inclined ground surface across the fault scarp, and $H$ is the scarp height, a vertical measurement between the top and base of the scarp (hollow circles), following the conventions of Caskey (1995). We also report the scarp width $(W)$, a horizontal measurement between the top and base of the scarp. All profiles measured from lidar. The distance of each topographic profile from the southeastern tip of the Meers fault is shown in kilometers $(\mathrm{km})$ in lower corner of each plot. Vertical exaggeration (V.E.) reported for each profile. 
(a)



(b)

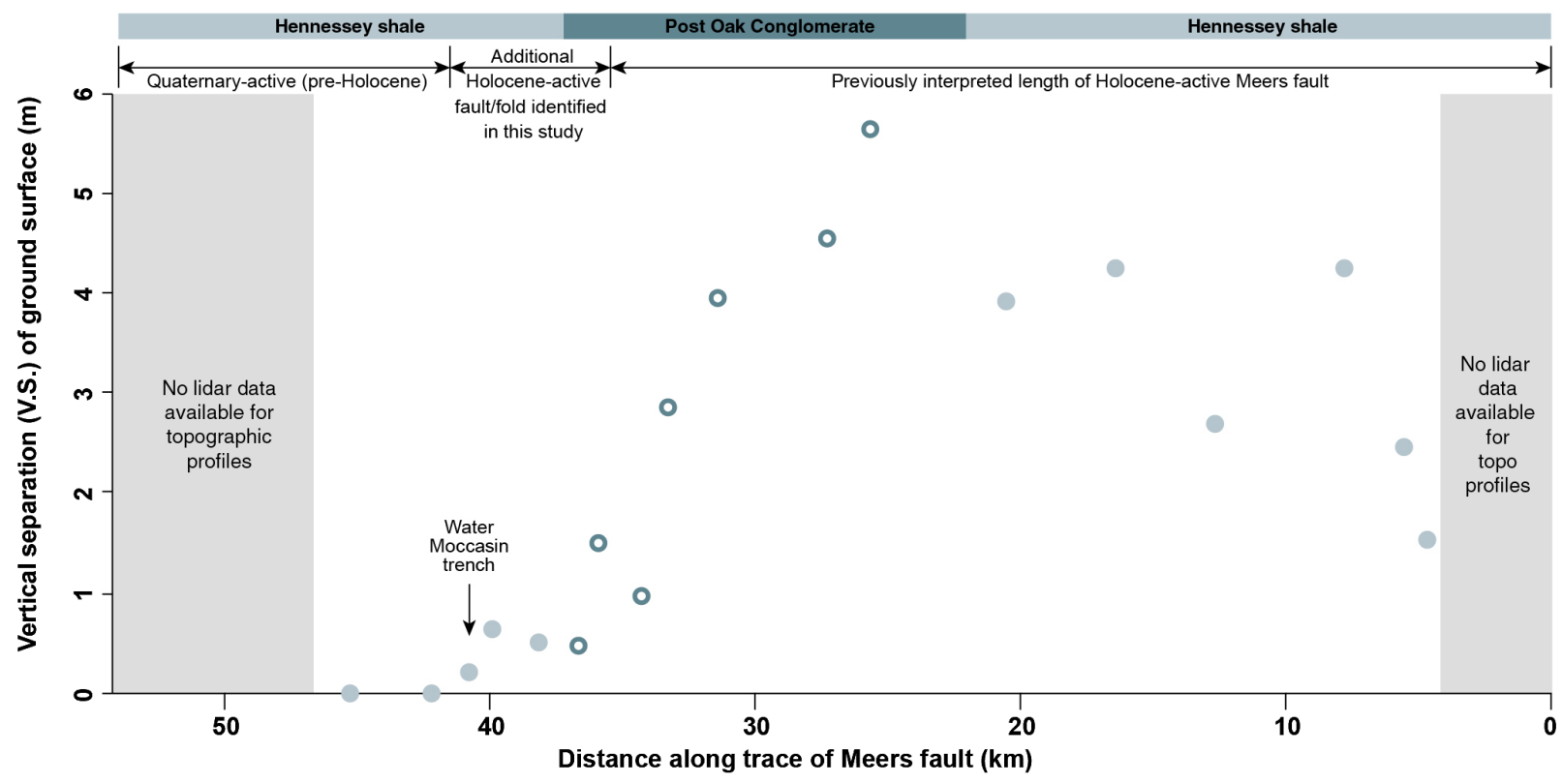

(c)

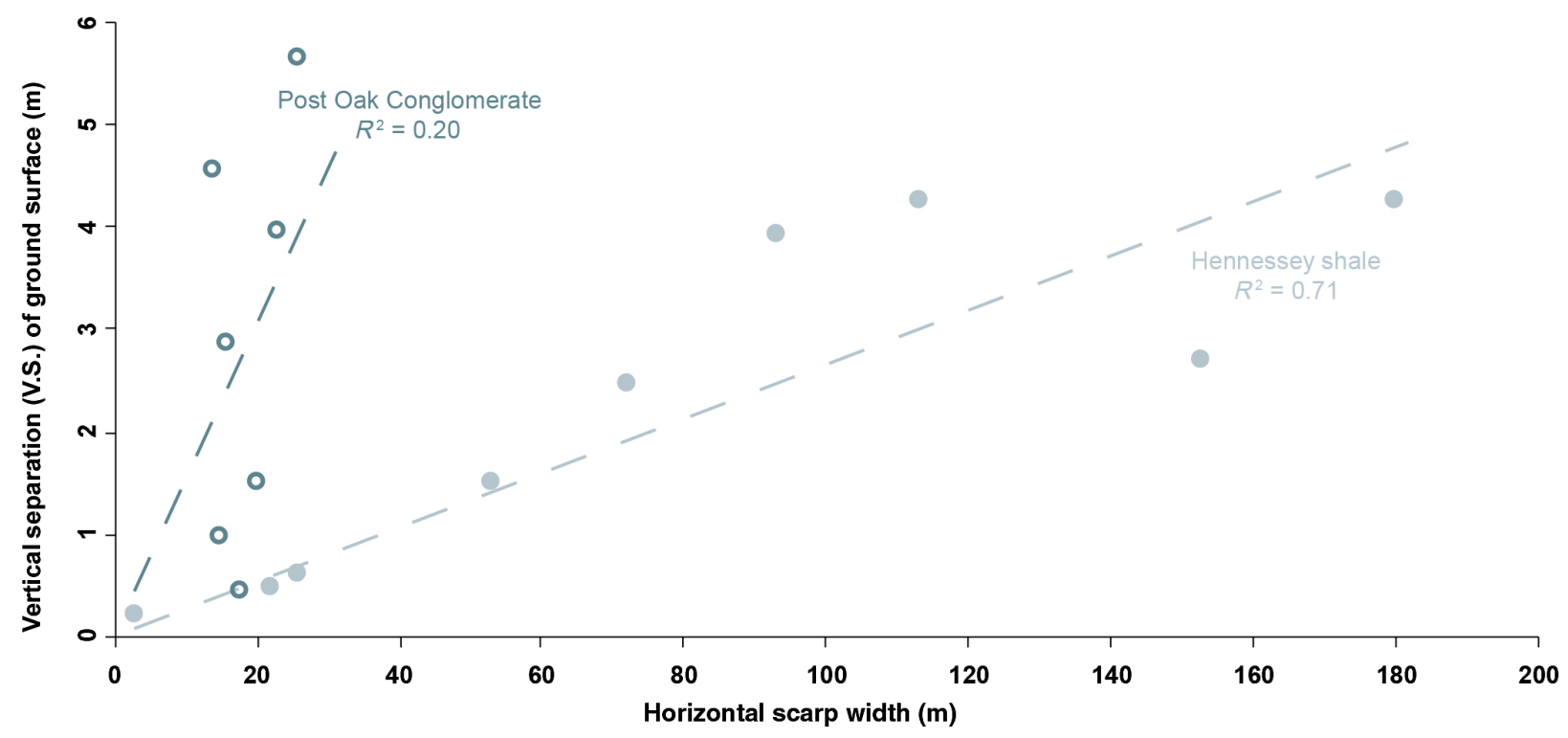

Figure 4. (a) Map showing the location of 18 lidar-derived topographic profiles along the Meers fault from this study. Profiles are labeled A-R. See Figure 3 for plot of each topographic profile. Distance along the Meers fault is measured from its southeastern tip $(0 \mathrm{~km})$. (b) Plot of vertical separation of the ground surface along the length of the Meers fault, distances correspond with the fault map above. Bedrock lithology along the fault indicated by bars across the top of the plot. Dark hollow circles are measurements taken in Post Oak conglomerate, lighter solid circles taken in Hennessey shale. (c) Plot of horizontal scarp width versus vertical separation of the ground surface. Point shading same as (b). Scarp width generally increases with larger vertical separation, but is typically much greater in the Hennessey shale than in the Post Oak conglomerate for similar values of vertical separation. We interpret this to reflect brittle fault displacements in Post Oak conglomerate and broad fold deformation over a wider zone in Hennessey shale. Alternatively, greater amounts of erosion and scarp diffusion may also explain wider scarps in the weaker, clay-rich Hennessey shale. Subsurface studies are needed to evaluate which explanation is appropriate. Dashed lines show linear fit to data points for each lithology. The color version of this figure is available only in the electronic edition. 


\section{Relationship between scarp width and vertical separation}

Our topographic profile analysis also provides insight about the relationship between scarp width and vertical separation, and how this relationship varies in different bedrock lithologies. We observe different scarp morphology in the two bedrock lithologies: the well-indurated Post Oak conglomerate and the weathered Hennessey shale (Fig. 4). Where the fault cuts Post Oak conglomerate, outcrops of conglomerate are exposed on the upthrown side of the scarp. Where the fault traverses Hennessey shale bedrock, the scarp is topographically subdued because of decimeter-scale vertical separations that have been accommodated over broad zones up to several meters wide, erosion on the upthrown side of the fault, deposition on the downthrown side of the fault, and anthropogenic alteration of the landscape. Our topographic profiles across the scarp indicate that the widest scarps occur in Hennessey shale, where we observe maximum vertical separation of $0.6 \mathrm{~m}$ the scarp width is $26 \mathrm{~m}$ (Fig. 4). In contrast, where maximum vertical separation in the Post Oak conglomerate is $5.6 \mathrm{~m}$ the scarp width is $26 \mathrm{~m}$. Although scarp width increases with greater vertical separation, regardless of bedrock lithology, the scarp width:vertical separation ratio varies between the two bedrock lithologies: 20:3 for scarps in the Post Oak conglomerate, and 100:3 for scarps in the Hennessey shale. Scarp width in the Hennessey shale is up to an order of magnitude larger than scarps with similar vertical separation in the Post Oak conglomerate (Fig. 4c).

Deformation of the Hennessey shale may form wider scarps because deformation occurs by a combination of brittle fault displacements and broad fold deformation over a wider zone. In contrast, deformation of the Post Oak conglomerate generally occurs as brittle failure in relatively narrow fault zones and generally lacks the broader wavelength affects from near-surface folding. Alternatively, the wider scarps in the Hennessey shale may be a function of erosion; the weathered Hennessey shale is a weak lithology relative to the well-lithified Post Oak conglomerate. Greater amounts of erosion and scarp diffusion may contribute to the formation of wider scarps in the weakened, clay-rich shale. Where the scarp is located in Hennessey shale, the broad wavelength over which decimeter-scale vertical separations are accommodated may explain why the northwest section of the Meers fault was previously not considered Holocene active.

\section{WM paleoseismic site}

The WM paleoseismic site is located where relatively thin Holocene deposits overlie Hennessey shale. The site is $\sim 15 \mathrm{~m}$ southeast of a small meandering ephemeral stream that flows roughly northeast to southwest (Fig. 5). We selected the trench location in the floodplain of the stream, which has experienced seasonal overbank flooding and deposition of sediment during historic time (D. Reeder, personal comm., 2016, family has owned property for more than $90 \mathrm{yr}$ ), with hopes that this site had relatively high sedimentation rates and the paleoseismic trench would expose datable material to bracket the ages of earthquakes. We excavated the WM trench $\sim 15$ m northwest of the irrigation ditch and perpendicular to a $\mathrm{N} 60^{\circ} \mathrm{W}$-trending scarp in the surface gradient (gentle $1^{\circ}-2^{\circ}$ slope to the southwest; Fig. 5). A lidar-derived profile at the WM site reveals $\sim 0.2 \mathrm{~m}$ of vertical separation of the ground surface across the scarp (Fig. 5c).

A 3-meter-wide irrigation ditch was excavated in $~ 1950$ $\sim 15 \mathrm{~m}$ east of the WM site along a low-relief channel to divert ephemeral stream flow (Fig. 5b). The subvertical walls of this irrigation ditch expose faulted stratigraphy and scarp-derived colluvial deposits (Fig. 5d). Permian Hennessey shale is in subvertical fault contact with inferred Holocene scarp-derived colluvium in both walls of the irrigation ditch. The subhorizontal erosional unconformity between inferred Holocene units and Permian Hennessey shale is exposed on both sides of the fault on the southeast side of the ditch where we estimate $\sim 1.5 \mathrm{~m}$ of vertical separation of this contact across the fault (Fig. $5 \mathrm{~d}$ ). Undeformed overbank silt deposits with $\mathrm{O}, \mathrm{A}$, and Bw horizon soil development as well as slump material from modern tree throw overlie the fault (Fig. 5d).

\section{Trench geologic units}

The WM trench exposed Hennessey shale, fluvial gravelly sands, ponded alluvium, and overbank flood deposits that thin and pinch out to the northeast, overbank deposits with strong, blocky, pedogenic structure, and scarp-derived colluvium (Fig. 6, see Fig. S3 for large-format, high-resolution photomosaics and trench logs of all trench walls, and Table S2 for detailed unit descriptions). The oldest unit in the trench is the Permian Hennessey shale (unit 5), consisting of deeply weathered and oxidized clay-rich shale. All younger units overlie unit 5 across an erosional unconformity. Unit 4 overlies Hennessey shale in the northern half of the trench and is a gray-brown massive silt with trace gravel, abundant carbonate nodules, and is overprinted with a blocky pedogenic structure and translocated clay films.

Stratigraphic units $3 \mathrm{a}-3 \mathrm{e}$ are a package of moderately inclined (apparent dips of $\sim 25^{\circ}-30^{\circ}$ to the northeast) interbedded fine to medium fluvial gravel and clayey silt deposits with a soil A horizon developed on the upper $1 \mathrm{~cm}$ of each fine-grained interbed (Fig. 6; Table S2). These soils represent stable surfaces between interbeds, minimal erosion, and primarily aggradation during the unit 3 depositional sequences. Subunits 3a-3d are fine-grained clast supported gravels to silty matrix supported gravels. Subunit $3 \mathrm{e}$ at the base of the sequence is a 10-20-centimeter-thick, massive, silty-clay with a buried A horizon developed on it. Basal deposits of unit 3 interfinger with unit 4 to the northeast (Fig. 6 and Fig. S3).

Stratigraphic unit 2 is a package of deposits that span the entire length of the WM trench and overlie units 3 and 4 . At 
(a)

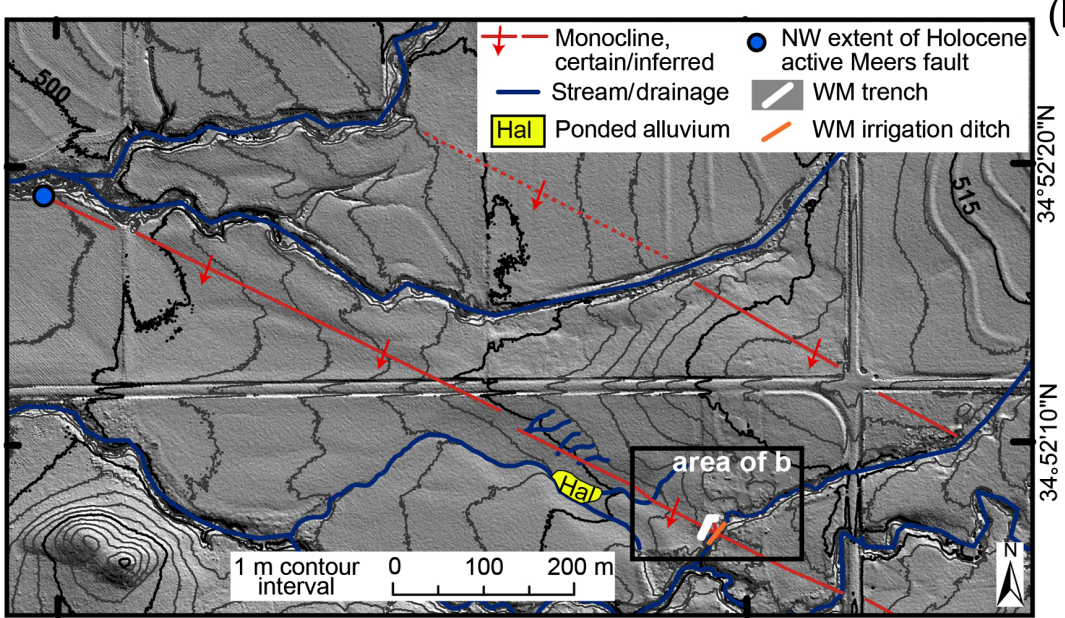

$98^{\circ} 42^{\prime} \mathrm{O}^{\prime \prime} \mathrm{W}$

$98^{\circ} 41 ' 30^{\prime \prime W}$

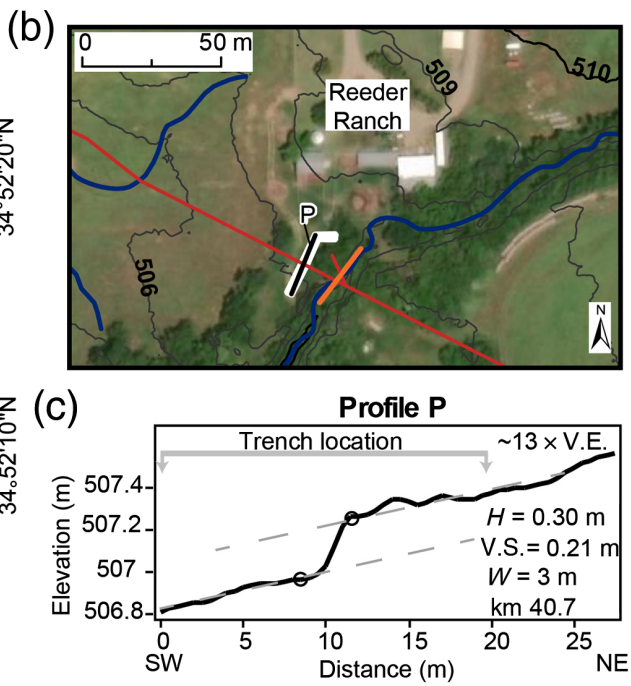

(d)

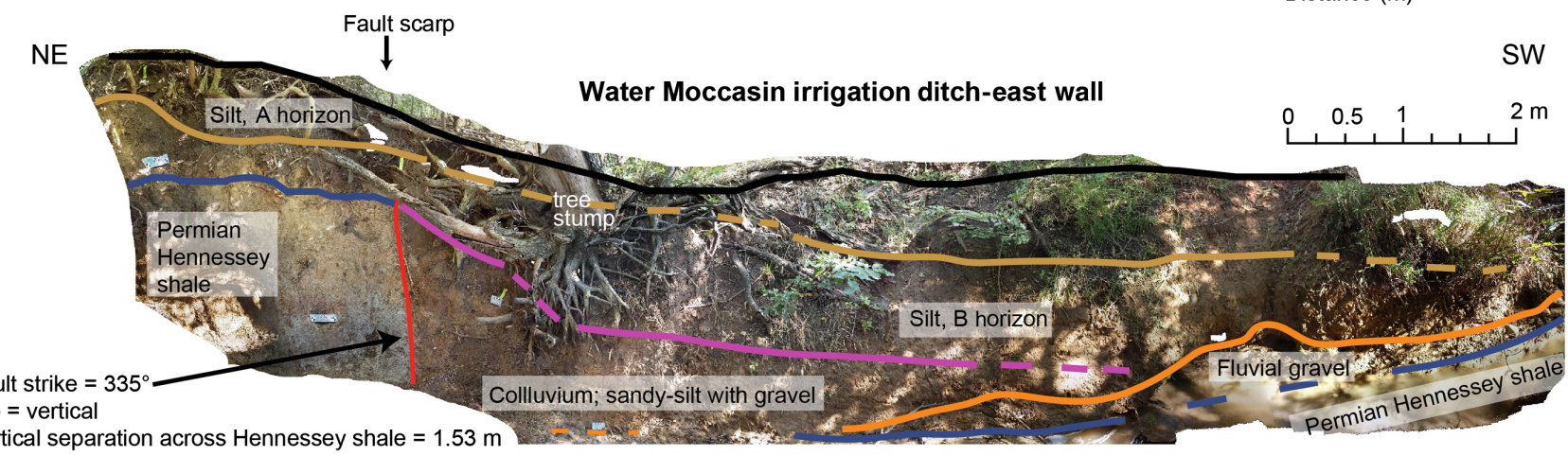

the northeastern-most part of the trench (see dogleg section of trench in Fig. S3f,h), unit 2 conformably overlies unit 4 . Farther south, beginning approximately at meter V4 in the trench and to the southwestern end of the trench, unit 2 overlies unit 4 , unit 3 , and Hennessey shale across an erosional unconformity. Subunit $2 \mathrm{a}$ consists of coarse-grained channel gravel in a sandy-silt matrix. From north to south, this unit grades laterally to subunits $2 \mathrm{~b}$ and $2 \mathrm{c}$ (Fig. 6 and Fig. S3), as clast size and abundance decrease and silt content increases to the south. Units $2 \mathrm{a}-2 \mathrm{f}$ are interbedded fluvial deposits of medium to coarse subrounded gravel (units $2 \mathrm{a}$ and $2 \mathrm{f}$ ), sandy-silt, silt, and clayey-silt deposits (units $2 \mathrm{~d}$ and $2 \mathrm{e}$ ). Subunit $2 \mathrm{~g}$ is a clayey silt with $\sim 20 \%$ fine-grained angular colluvial clasts derived from unit 4 , and overlain by a massive silt, subunit 2 e. Subunit $2 \mathrm{~g}$ infills a pre-existing $20 \mathrm{~cm}$ trough-a topographic low above the unit 3 sequence (Fig. 6, V9-V12, and Fig. S3, V8-V11). Subunit $2 \mathrm{f}$ is a coarse-grained gravel deposit and caps tilted beds of unit 3. Subunits $2 \mathrm{~d}$ and $2 \mathrm{e}$ are sandy-silt overbank deposits with fine-grained, subrounded clasts; and are interbedded with 2-centimeter-thick dark silt layers with soil development (Fig. 6 and Fig. S3; Table S2).

Unit 1 is a package of massive silt deposits that onlap older stratigraphy across a buttress unconformity and thin or pinch out to the northeast (Fig. 6 and Fig. S1). Subunits $1 \mathrm{c}$ and $1 \mathrm{~b}$ are massive silts with deep soil development, gradationally transitioning from irregular to prismatic pedogenic structure
Figure 5. (a) Contour map of the northwest end of the Holocene active Meers fault. Contours derived from lidar digital elevation model, $1 \mathrm{~m}$ contour interval. The fault is expressed as a broad monoclinal fold scarp, where contours are elongate and inflected along the trend of the scarp from the center of the image and approaching the northwestern tip of the newly identified Holocene-active section of the fault (blue dot). Ephemeral drainages are incised into the upthrown side of the fault near the center of the map. The Water Moccasin (WM) trench (white line) is located just south of Reeder Ranch, in an alluvial surface adjacent to a small stream. (b) Map of the WM trench site, trench in white and anthropogenic irrigation ditch shown as adjacent solid line to east. (c) Topographic profile P with $0.21 \mathrm{~m}$ of vertical surface offset across the scarp (Fig. 3). Location of the WM trench shown above the profile. (d) Faulted stratigraphy exposed in the southeast wall of the irrigation ditch adjacent to the trench. Hennessey shale is in vertical fault contact with fault-derived colluvium. Massive silt with soil development caps the brittle fault, and is partially covered by roots and tree throw material. After cleaning the exposure, this sharp fault contact is visible across the floor of the ditch and on the northwest wall of the ditch and strikes $335^{\circ}$. The color version of this figure is available only in the electronic edition.

with depth. Subunit 1a is a dark brown to black bioturbated silt with some organic material and A soil horizon development (Fig. 6). The uppermost unit is historic fill material that contains anthropogenic features such as glass fragments, nails, and steel wire, and was emplaced at the trench site during ranching activities (D. Reeder, personal comm., 2016). We do not observe any evidence that native deposits were stripped away due to ranching activities. 
(a)

$\mathrm{NE}$

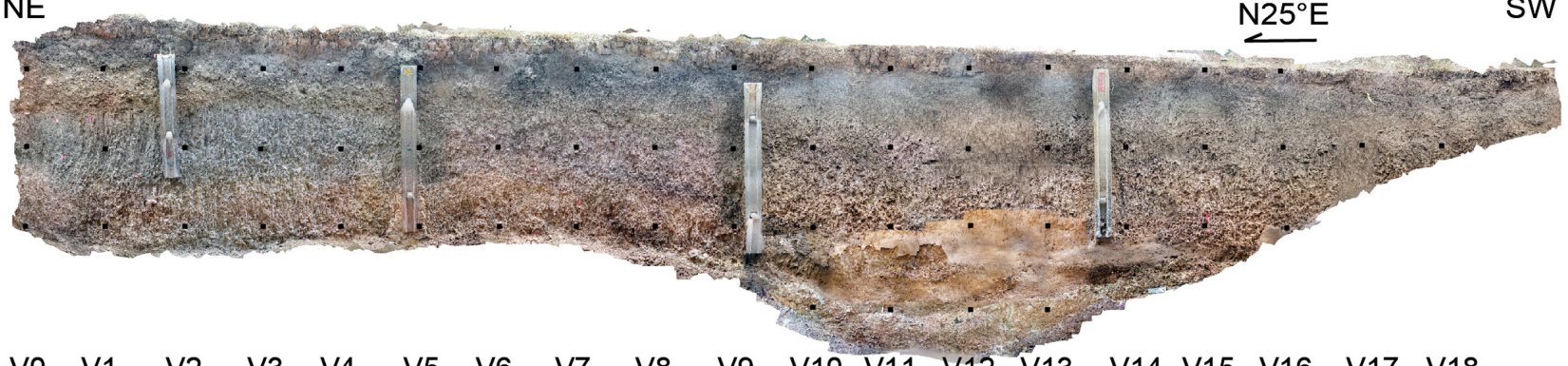

(b)

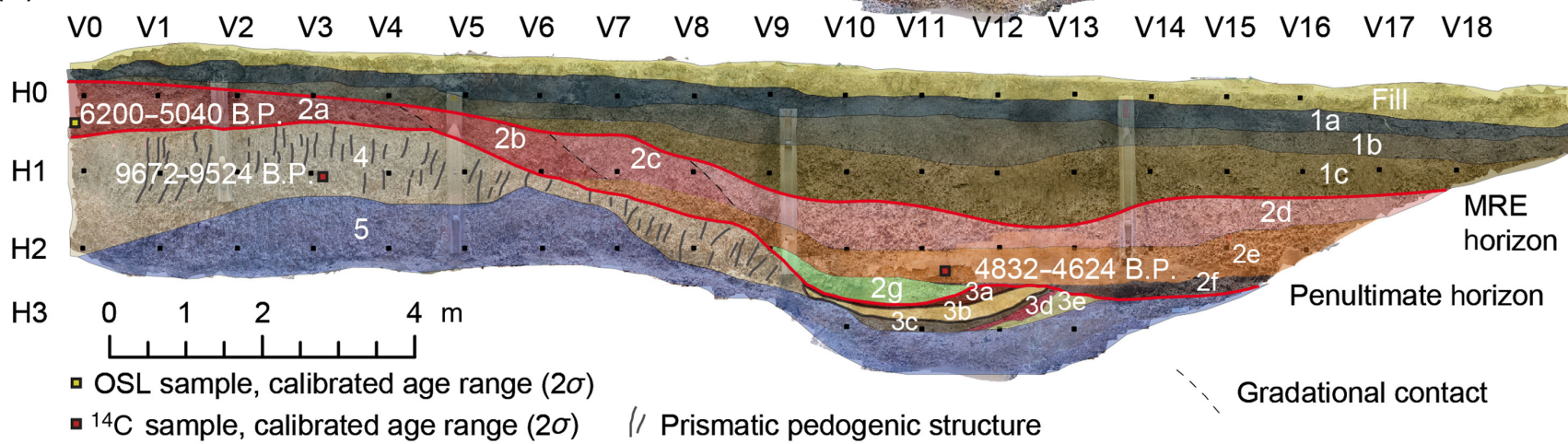

\section{Geochronologic age results}

Deposits exposed in the trench yielded few samples of organic material for $\mathrm{RC}\left({ }^{14} \mathrm{C}\right)$ dating. We obtained age results from four samples, one from macrocharcoal that was easily visible in the trench wall, and three from microcharcoal samples that were separated from bulk sediment samples. We calibrated the $\mathrm{RC}$ ages to the ${ }^{14} \mathrm{C}$ curve (Reimer et al., 2013) and report them with $2 \sigma$ uncertainty: unit 4, 9672-9524 cal B.P.; unit 3b, 61705919 cal B.P.; unit 2f, 4832-4624 cal B.P.; and the base of unit 1c, 3167-2974 cal B.P. (Table 1; Fig. 6 and Fig. S3).

We collected two samples from fluvial unit $2 \mathrm{f}$ and $2 \mathrm{a}$ for OSL dating (Fig. 6 and Fig. S3). A concern with OSL dating of fluvial deposits is the potential for partial bleaching (incomplete resetting), resulting in anomalously old burial ages (Gray et al., 2015). The preliminary OSL analyses yielded late Pleistocene (Table 2) that were considerably older than the Holocene ${ }^{14} \mathrm{C}$ ages obtained from AMS detrital charcoal from the same units. These results suggest that the OSL samples may have been only partially reset and the late Pleistocene results are much older than the true burial age of these deposits. Therefore, more than 50 aliquots were processed to identify a more representative age signal from several potentially bleached grains (see "minimum age" in Table 2). The sample from unit $2 \mathrm{f}$ yielded a minimum age range of 8360-5960 yr B.P. ( $2 \sigma$ uncertainty) and the sample from unit $2 \mathrm{a}$ yielded a minimum age of $6200-5040$ yr B.P., with $2 \sigma$ uncertainty (Table 2).

\section{Prehistoric earthquakes at the WM site}

We document evidence for coseismic up-on-the-northeast monoclinal warping of 1-2 $\mathrm{m}$ of Holocene alluvial deposits and
Figure 6. East wall of the WM trench. This trench exposure preserves evidence for two Holocene surface-folding earthquakes. (a) Uninterpreted photomosaic of the east wall with a $1 \mathrm{~m} \times 1 \mathrm{~m}$ grid (small black squares). Vertical gray rectangles are hydraulic shores. The sharp horizontal contrast near grid row $\mathrm{H} 2$ is an artifact of combining two separate photomosaics derived from photos taken in different sunlight conditions. (b) Interpreted trench log with stratigraphic unit contacts (thin lines) and inferred earthquake horizons (thick lines; Fig. S3; Table S2, available in the supplemental material to this article). Sample locations and geochronologic ages are shown. Prismatic pedogenic structure in upper part of unit 4 (discontinuous and subvertical thin black lines) is folded across the trench exposure. See Figure $\$ 3$ for high-resolution photomosaic and trench logs for both trench walls and both walls of a dogleg section of the trench. MRE, most recent earthquake; OSL, optically stimulated luminescence. The color version of this figure is available only in the electronic edition.

weathered Permian Hennessey shale in the WM trench (Fig. 6 and Fig. S1; grid meters V6-V12). We identified two Holocene surface-deforming earthquakes in the alluvial stratigraphy (Fig. 6 and Fig. S1) and a possible third older event. Fold deformation observed in the WM paleoseismic excavation combined with the topographic analysis reveals the along-strike transition from brittle surface faulting on the southeast Meers fault to surface folding on the northwest Meers fault occurs at the lithologic contact between Permian Post Oak conglomerate and Hennessey shale (Fig. 4).

We retrodeformed the trench stratigraphy to model the stages of fault-related vertical deformation, deposition, and erosion of geological units (Fig. 7; Table 3). In this model, we account for the vertical component of coseismic surface folding while maintaining thickness of geologic units present during 
each event. We do not evaluate the lateral component of slip here, and we assume no considerable stratigraphic thickness changes $(>20 \mathrm{~cm})$ occurred along the fold scarp in a direction in and out of the trench. We also maintain surface-line length for earthquake horizons and key stratigraphic in the retrodeformation. We remove vertical separation from event horizons in a stepwise fashion conserving unit line lengths. Subsequently, we summarize the sequence of events in our preferred model, including earthquake evidence and mapped trench stratigraphy.

MRE, E1. The MRE folded unit 2 and older units across a down-to-the-southwest monocline (Table 3). Units $1 \mathrm{~b}$ and $1 \mathrm{c}$ onlap (buttress unconformity) against this fold scarp and unit 1a buries and overlaps these units across the scarp. Units 1a-1c each thicken to the southeast with unmodified upper contacts (Fig. 6). We document $\sim 0.8 \mathrm{~m}$ of stratigraphic vertical separation of the upper contact of unit 2 across the MRE fold scarp (Fig. 6 and Fig. S1; grid meters V2-V12), which is a minimum value, due to possible erosion of the upper parts of unit 2 on the upthrown side of the fold. We interpret thicker sedimentation south of the fault to have brought the ground surface slope closer to the natural floodplain gradient in the basin of $\sim 2^{\circ}$, and partially concealing surficial evidence of the fold scarp. For example, our lidar-derived topographic profile revealed only $0.22 \mathrm{~m}$ of vertical separation of the ground surface (Fig. $5 \mathrm{c}$ ), which underestimates the $\sim 0.8 \mathrm{~m}$ of stratigraphic vertical separation that occurred in the MRE (Fig. 7).

The MRE, E1, likely occurred via blind rupture of the subvertical Meers fault at the WM site. Unit 2 was at the ground surface during E1 (Fig. 7h). This blind fault slip generated a minimum vertical displacement of $\sim 0.8 \mathrm{~m}$ due to monoclinal folding, uplifted the channel gravel deposits of unit $2 \mathrm{a}$ on the northeast, and folded fluvial units $2 \mathrm{~b}-2 \mathrm{f}$ on the southwest (Fig. 7h).

Combined, evidence for this event indicates E1 was a "very likely" surface-deforming earthquake at the WM site (Table 3). Earlier researchers found a range of lateral- to vertical-slip ratios from 1.3:1 (Kelson and Swan, 1990; Swan et al., 1993) to 5:1 (Crone and Luza, 1990) for the Meers fault. We document $0.8 \mathrm{~m}$ of vertical separation across the fault, and based on these vertical- to lateral-slip ratios we estimate a range of $1-4 \mathrm{~m}$ of lateral slip on this section of the fault in the MRE. We do not directly evaluate the lateral component of slip in this study, and this would require $3 \mathrm{D}$ excavations across a region much wider than possible in our deep slot trench.

Penultimate earthquake (E2). The penultimate earthquake occurred when units 4 and 3 were at the ground surface (Table 3; Fig. 7). Units 3 and 4 were folded up on the northeast, down on the southwest side of the fault. Material from unit 4 was eroded along the crest of the fold scarp and deposited as scarp-derived colluvium (unit $2 \mathrm{~g}$ ) onto the penultimate earthquake horizon (Fig. 7d). Subsequently, deposition of fluvial units $2 \mathrm{a}-2 \mathrm{f}$ onlap and overlap the scarp with thicker deposits southwest of the fold scarp, which reduced the relief across the fold scarp and helped reduce the overall surface gradient back to a $2^{\circ}$ slope to the southwest (Fig. 7f). On the downthrown, southwest side of the fold scarp, interbedded alluvial and fluvial gravel deposits of unit 3 are tilted $\sim 25^{\circ}-30^{\circ}$ toward the northeast. These inclined beds are truncated across a sharp, subhorizontal erosional unconformity (see V12 and V13 in Fig. 6, and Fig. S1).

The penultimate event horizon in the WM trench is vertically separated a total of $\sim 1.6 \mathrm{~m}$ across the fold scarp, with $\sim 0.8 \mathrm{~m}$ of this displacement due to the MRE, described earlier. Thus, the penultimate event created a minimum of $\sim 0.8 \mathrm{~m}$ of vertical separation across the fold scarp (Fig. 6 and Fig. S1). This is a minimum value due to erosion of the fold scarp and subsequent deposition at the base of the scarp (Fig. 7).

The penultimate earthquake likely occurred via blind rupture on a subvertical Meers fault (e.g., Jones-Cecil, 1995) at the WM site. Stratigraphic evidence for E2 indicates that is was a "very likely" surface-deforming earthquake (Table 3). This fault-related folding generated a minimum up-to-the-northeast stratigraphic vertical separation of $\sim 0.8 \mathrm{~m}$. Given the range of range of lateral- to vertical-slip ratios established on the Meers fault (Crone and Luza, 1990; Kelson and Swan, 1990; Swan et al., 1993), we estimate a range of 1-4 $\mathrm{m}$ of lateral slip in the penultimate earthquake.

Antepenultimate earthquake (E3). The antepenultimate event, or third earthquake back in time, may have occurred when unit 4 was exposed at the ground surface. This event has the weakest stratigraphic evidence, and is ranked as a "probable" event (Table 3). Unit 4 is $1 \mathrm{~m}$ thick on the northeast side of the fold scarp, and missing on the southwest side of the scarp (Fig. 6 and Fig. S1). We interpret a surface-deforming event that channelized surface flow along the base of the monocline, subparallel to the fold scarp, and eroded unit 4 on southwest side of the monocline (Fig. 6 and Fig. S1). After the event, fluvial deposits of unit 3 were laid down, within channel scoured topographic lows. At meters V9-V13 in the trench the upper horizon of the Hennessey shale has a 20-centimeterdeep topographic depression on the downthrown side of the fold (Fig. 6 and Fig. S1). This topographic low was slowly infilled by units $3 a-3 e$, a sequence of interbedded fine- to medium-grained fluvial sediments with soil A horizon development on the upper $1 \mathrm{~cm}$ of each interbed. Units 3a-3e onlap against unit 4 toward the northeast (Fig. 6 and Fig. S1; grid V10-V13).

We cannot directly assess vertical separation across unit 4 because it is missing southwest of the scarp. Below this unit, the top of the Hennessey shale exposed in the trench does not appear to have greater vertical separation than the amount vertical separation measured for the E2 horizon. However, the duration of time and amount of erosion represented by 




(erosional unconformity).

C Penultimate EQ, $\sim 0.8 \mathrm{~m}$ of vertical offset (minimum), deformation of units 3 , 4 , and 5.

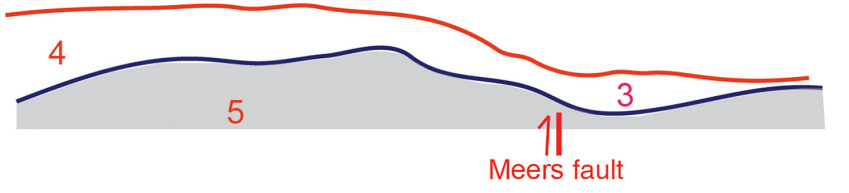

D Erosion of the scarp, (unit 4) and deposition of a colluvial wedge $(2 \mathrm{~g})$, unit 3 is eroded/ truncated by (2f).



Note: Units $2 \mathrm{~g}$ $2 \mathrm{f}$, and $2 \mathrm{e}$ are only shown in stage $D, E$ \& $F$ and are included in unit package 2 (steps G \& H below) for simplicity in later stages.

E Deposition of ponded alluvium/flood deposits (unit 2e), infilling relief across the scarp.

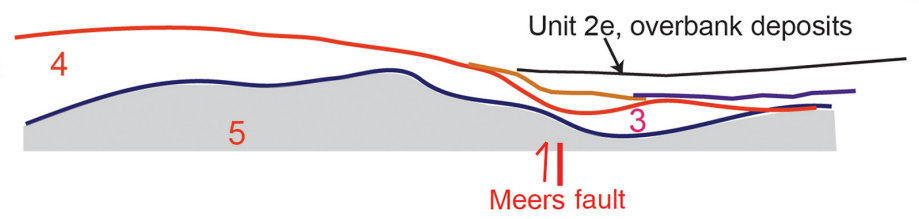

F Deposition of alluvial units $2 a-2 g$, overlapping the scarp.

G MRE, $\sim 0.8 \mathrm{~m}$ of displacment, uplift and folding of unit 2.



\section{H Deposition of undeformed silt (unit 1) that onlaps and overlaps the scarp.}
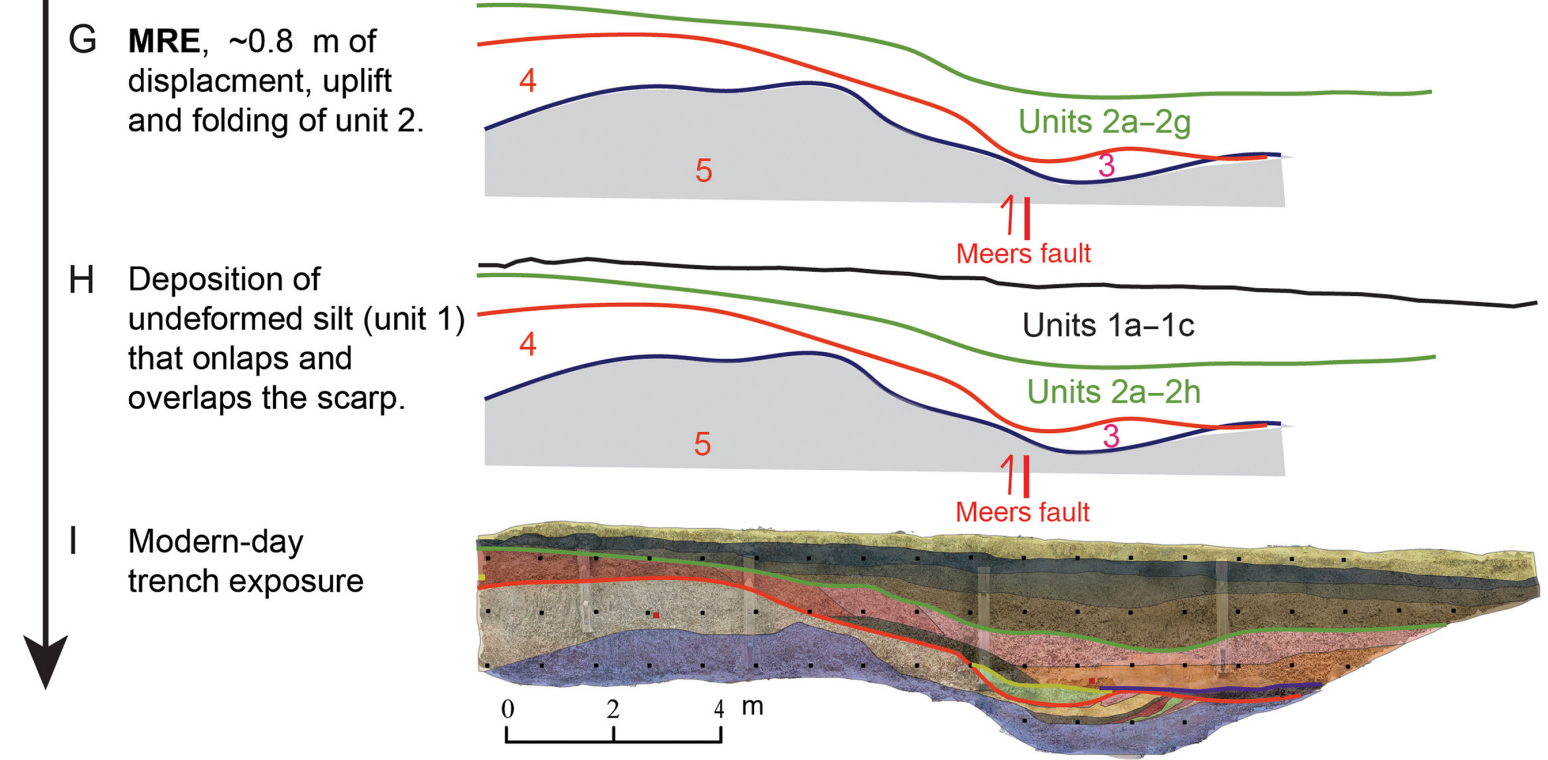

Figure 7. Schematic reconstruction deformation history for the east wall of the WM trench. The model incrementally restores progressive deformation at the WM site and illustrates interpreted erosion and deposition of Holocene units across the fold scarp above a blind Meers fault. The bottom panel is the stratigraphy and geometric relations mapped in the east wall of the trench (from Fig. 6b). Contacts were retrodeformed by maintaining unit thickness for buried stratigraphy below each iterative ground surface, and line lengths are maintained. EQ, earthquake. The color version of this figure is available only in the electronic edition. 


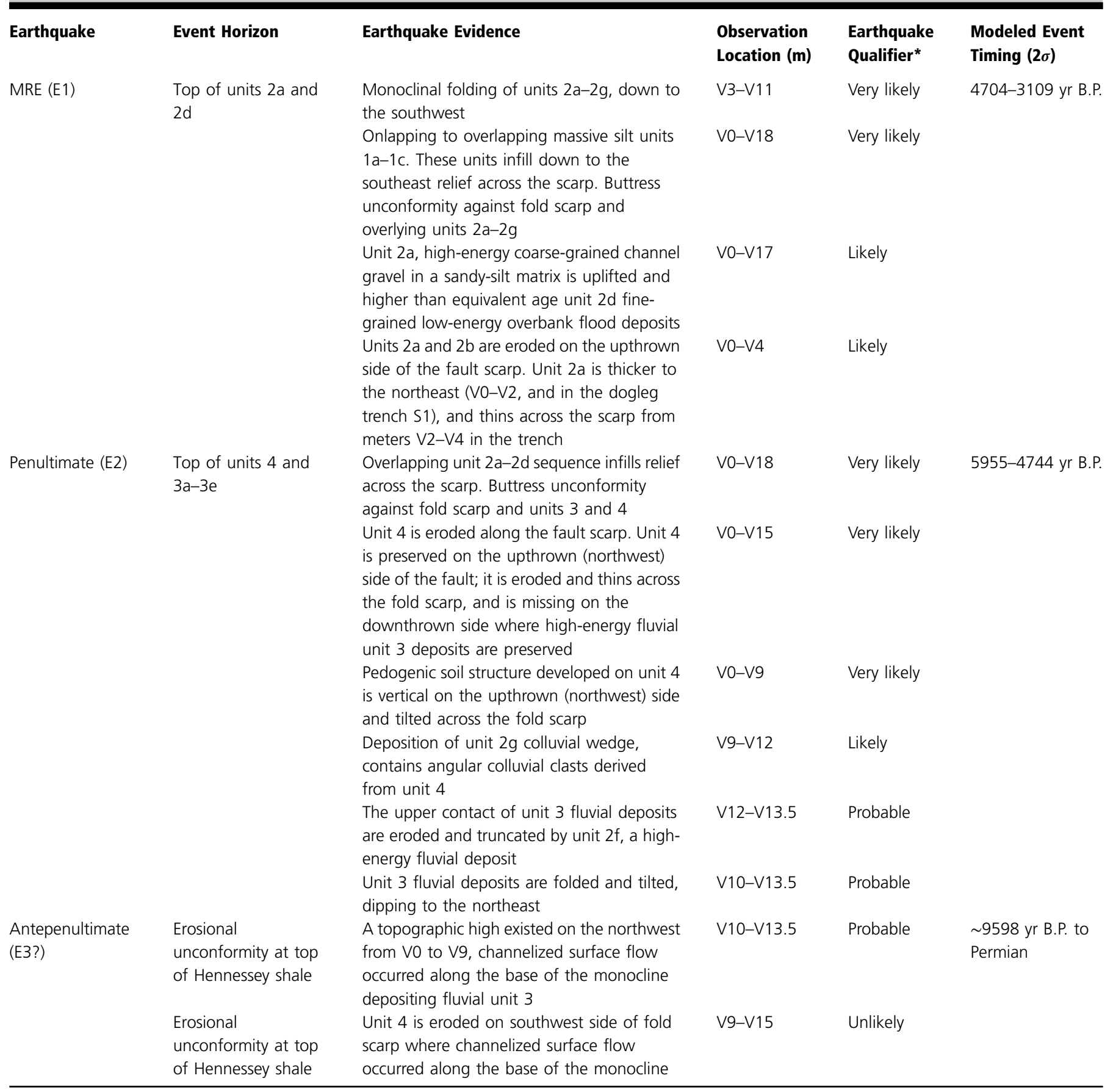

MRE, most recent earthquake.

*Earthquake qualifiers based on criteria outlined in Scharer et al. (2007).

this erosional unconformity between bedrock and overlying Holocene deposits is unknown. Erosion of unit 4 and onlapping unit 3 relationships only occur across a few meters near the toe of the monocline, and are not observed elsewhere within the trench. This suggests that repeated onlapping to overlapping stratigraphic sequences and associated unconformities are intimately related to several folding events along the monocline.

\section{Earthquake timing}

We use stratigraphic ordering information and ${ }^{14} \mathrm{C}$ age results from the WM paleoseismic trench to statistically evaluate the age of stratigraphic units and model the timing of surfacedeforming earthquakes with OxCal 4.3 (see Data and Resources; Bronk Ramsey, 2009; Lienkaemper and Bronk Ramsey, 2009; Fig. 8; Table S3). Because stratigraphic units lacked abundant organics, we were only able to bracket the 


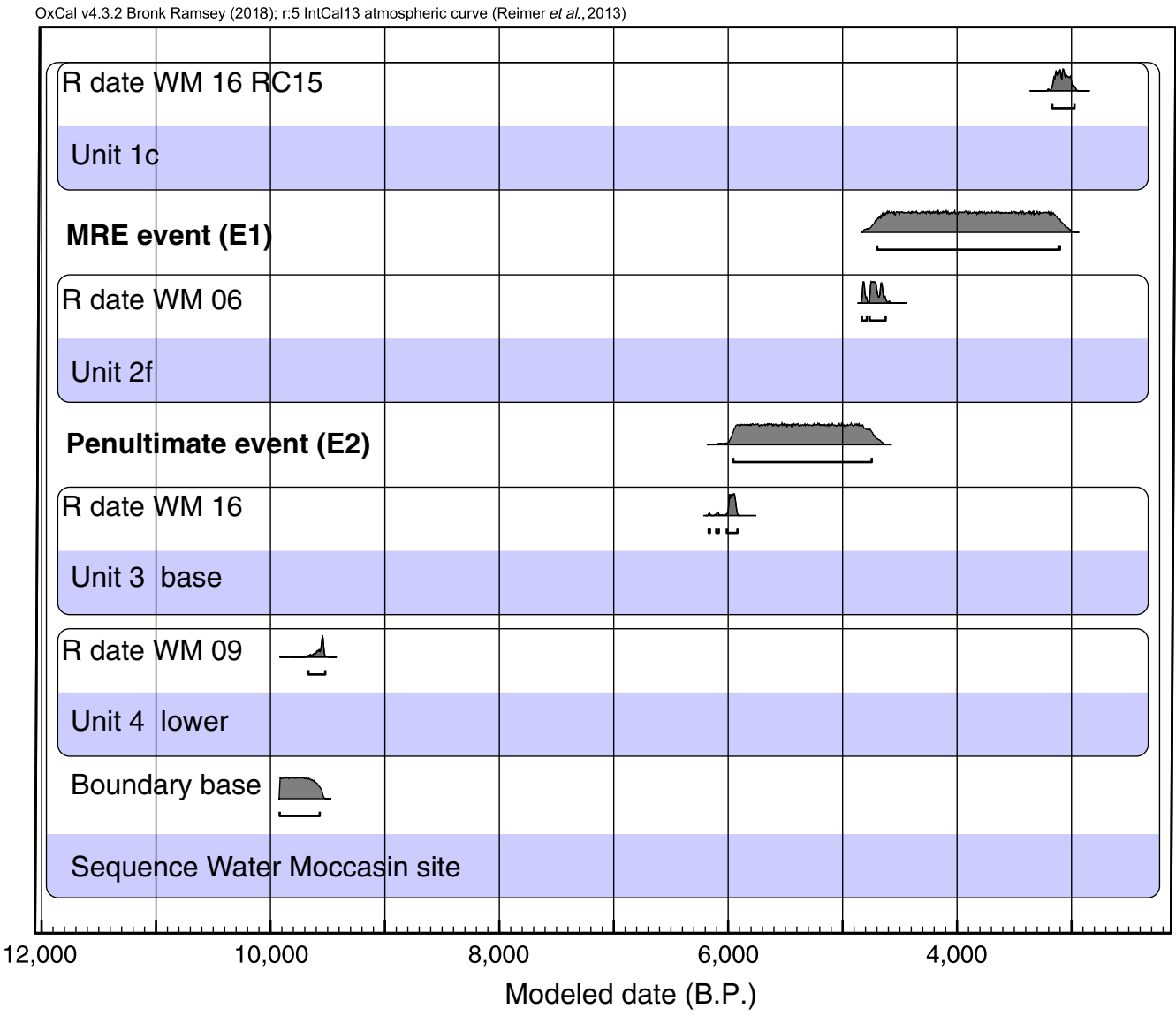

Figure 8. OxCal Bayesian statistical age model of calibrated ${ }^{14} \mathrm{C}$ ages for the WM trench with resulting modeled age ranges for Holocene earthquakes E1 and E2. Stratigraphic units are youngest to oldest, top to bottom, and probability density functions for each charcoal sample constrain earthquake age ranges (see Bronk Ramsey, 2009; Lienkaemper and Bronk Ramsey, 2009). RC, radiocarbon. The color version of this figure is available only in the electronic edition.

(compare Fig. 8 and Fig. S3, and compare Tables S3 and S4). For example, the timing range for the MRE (E1) varies by only a few decades between the preferred and alternate models. The maximum and minimum timing limits for the penultimate event (E2) are older by one to six centuries, respectively, in our alternate model.

\section{DISCUSSION}

\section{Summary and comparison with other sites}

The along-strike transition from surface faulting on the southeast Meers fault to surface folding on the northwest Meers fault occurs at the lithologic contact between Permian Post Oak conglomerate and Hennessey shale. We lengthen the Holocene-active trace of the Meers fault $6.1 \mathrm{~km}$ to the northwest based on our interpretation of high-resolution topographic data coupled with field observations and a paleoseismic trench. Surface deformation is subtle along the northwest section of the Meers fault and was mapped primarily from lidar-derived

MRE with one maximum and one minimum limiting $\mathrm{RC}$ age (Table S3). The timing of the MRE is loosely constrained between 4704 and 3109 yr B.P. ( $2 \sigma$ uncertainty). The penultimate surface-deforming earthquake is modeled to have occurred between 5955 and 4744 yr B.P. ( $2 \sigma$ uncertainty; Table S3).

We also provide an alternate OxCal model (Fig. S4; Table S4) that incorporates two minimum OSL age results with the ${ }^{14} \mathrm{C}$ results. Both OSL minimum age estimates have large uncertainty (Table 2). It is possible that although we attempted to isolate and remove partially bleached grains via a multialiquot dating approach, some quartz grains in the aliquots that yielded younger ages are partially bleached. If this is the case, these few older grains may skew our minimum age interpretation to be slightly older than their true burial ages, for this reason these results are not incorporated in our preferred OxCal model (Fig. 8). Nevertheless, incorporating the two OSL ages into an alternate OxCal model produces earthquake timing results that are broadly similar to our preferred model low-sun-angle hillshade maps with closely spaced contours (Figs. 2 and 5). We find geomorphic evidence of a break in slope in lidar derivatives and monoclinal fold deformation associated with two Holocene surface-deforming earthquakes in the WM paleoseismic trench (Figs. 3, 4b, and 6). No scarp was observed farther to the northwest along the mapped Quaternary trace of the fault (Figs. 3 and $4 \mathrm{~b}$ ).

At the WM site, the MRE (E1) is constrained between 4704 and 3109 yr B.P. ( $2 \sigma$ uncertainty), and the penultimate event (E2) occurred between 5955 and 4744 yr B.P. ( $2 \sigma$ uncertainty). These two surface-deforming events exhibit similar northeastside-up monoclinal deformation, and our reconstruction shows $\sim 0.8 \mathrm{~m}$ of stratigraphic vertical separation in each of these events (Fig. 7). Ratios of left-lateral to vertical slip established on the southeast Meers fault (Crone and Luza, 1990; Kelson and Swan, 1990; Swan et al., 1993) suggest a range of 1-4 m of left-lateral slip for $0.8 \mathrm{~m}$ of vertical separation in both the MRE and penultimate surface-deforming earthquakes at the WM site. We document an older stratigraphic section and 
earlier surface-deforming earthquakes than documented in previous paleoseismic investigations on the southeast section of the Meers fault, which identified between 1 and 2 surface faulting events in the last $3400 \mathrm{yr}$ (i.e., Madole, 1988; Crone and Luza, 1990; Kelson and Swan, 1990).

We did not identify evidence for a younger surfacedeforming event, about $\sim 1200 \mathrm{yr}$ B.P., in the WM trench, which has been documented along the southeast section of the Meers fault by Crone and Luza (1990) and Kelson and Swan (1990). This $\sim 1200$ yr B.P. surface-rupturing earthquake may not have propagated as far to the northwest as the WM site, thus its rupture length did not exceed $41 \mathrm{~km}$, but was at least $30 \mathrm{~km}$ long because it was observed at the Valley site by Kelson and Swan (1990). Alternatively, slip on the northwest section of the fault could have been minor in the $\sim 1200 \mathrm{yr}$ B.P. earthquake and may have not produced enough surface deformation to be detectable in our trench. The MRE on the northwest Meers fault at the WM site (4704-3109 B.P.) likely correlates with the older, penultimate earthquake about 2900-3400 B.P. on the southeast section of the Meers fault (Crone and Luza, 1990; Kelson and Swan, 1990). The penultimate event at the WM site (5955-4738 B.P.) is older than any previously identified earthquakes anywhere on the Meers fault, and expands the Meers fault earthquake record by an additional 2000$3000 \mathrm{yr}$ back in time. Along the northwest Meers fault, geomorphic expression of the fault is subtle as a result of both fold deformation in Hennessey shale bedrock, and a longer interval ( $\sim 3100-4700 \mathrm{yr}$ ) since the most recent surface-deforming earthquake, whereas the southeast section of the fault has more youthful scarps resulting from a more recent surface-rupturing earthquake that produced fault rupture of the ground surface rather than folding and surface warping.

\section{Implications for surface rupture and seismic hazard}

We find $\sim 0.8 \mathrm{~m}$ of vertical surface displacement in each of the last two surface-deforming earthquakes on the northwest Meers fault, and a range of 1-4 m of left-lateral slip based on ratios of lateral to vertical slip determined on the southeast Meers fault. Given empirical scaling relationships between fault displacement and rupture length (Wells and Coppersmith, 1994), for $1 \mathrm{~m}$ average lateral displacement we estimate fault rupture length $>40 \mathrm{~km}$, and for $1 \mathrm{~m}$ maximum lateral displacement we estimate fault rupture length $>27 \mathrm{~km}$. Using a lateral slip value of $4 \mathrm{~m}$ for both average and maximum displacements estimated surface fault rupture lengths range from 59 to $118 \mathrm{~km}$, far exceeding the mapped Holocene and Quaternary fault lengths. For this reason, we prefer the lateral- to vertical-slip ratio of 1.3:1 (Kelson and Swan, 1990; Swan et al., 1993), and $1 \mathrm{~m}$ of lateral slip and $0.8 \mathrm{~m}$ vertical are the preferred values at the WM site. Using the same empirical relationships (Wells and Coppersmith, 1994), for $0.8 \mathrm{~m}$ vertical (reverse) displacement we estimate fault rupture length $>21 \mathrm{~km}$. Based on these calculations, it is likely that events E1 and E2 had an SRL greater than $\sim 6.1 \mathrm{~km}$, and this section of the fault must rupture with the southeast section of the Meers fault.

If surface rupture observed on the southeast Meers $~ 1200$ B.P. did not occur along the northwest Meers fault, then this could indicate a complex history of bimodal rupture, with some large earthquakes rupturing the entire $\sim 43 \mathrm{~km}$ length of the fault, and other large earthquakes rupturing shorter sections of the fault. Greater cumulative vertical surface deformation along the southeast section of the fault (Fig. 4b) and our paleoseismic results indicate that the northwest section of Meers fault experiences smaller vertical displacements in surfacerupturing earthquakes and has not experienced as many Holocene surface-deforming earthquakes as the southeast Meers fault.

SRL has been empirically shown to correlate with the magnitude of an earthquake (Wells and Coppersmith, 1994). We extend the Holocene-active length of the Meers fault from $\sim 37$ to $\sim 43 \mathrm{~km}$, and using equation (1) from Wells and Coppersmith (1994):

$$
M=a+b \times \log (\mathrm{SRL})
$$

in which $M$ is earthquake magnitude, $a$ and $b$ are regression coefficients based on a global dataset of historic earthquake magnitudes, and SRL, we estimate that surface rupture along the $\sim 43$-kilometer-long Holocene-active Meers fault would produce an $M_{\mathrm{w}} 7.0$ earthquake, regardless if the strike-slip or reverse-fault coefficients $(a, b)$ are used. Using the same relationship, a 37-kilometer-long rupture would produce an $M_{\mathrm{w}} 6.9$ earthquake. This analysis provides further evidence that the Meers fault poses a significant seismic hazard for the CEUS.

\section{CONCLUSIONS}

Integration of lidar topography, balloon-based SfM topography, and historical aerial photographic data allows us to characterize subtle geomorphic evidence of surface folding along the northwest section of the Meers fault. These data, coupled with geochronologic ages from deformed alluvial stratigraphy at the WM paleoseismic trench, indicate that the Holocene-active Meers fault should be extended $6.1 \mathrm{~km}$ to the northwest on active-fault maps. We document linear escarpments, closed depressions on the downthrown block, and increased channel incision on the upthrown block as additional geomorphic evidence for recent fault activity along this northwest stretch of the fault. We find long wavelength deformation (monoclinal folding) of the surface where the fault traverses Permian Hennessey shale bedrock and show that this lithology yields broader scarp width $(W)$ than the Permian Post Oak conglomerate. Using fault-perpendicular topographic profiles, we show that the northwest section of the Meers fault has decimeterscale fold-related surface offsets and that vertical separation of the ground surface decreases toward the northwest and southeast tips of the $\sim 43$-kilometer-long Meers fault. We do 
not interpret the northwesternmost $\sim 11 \mathrm{~km}$ of the fault to be Holocene active based on a lack of surface expression and the decreasing vertical surface offset along the lengthened $\sim 6.1 \mathrm{~km}$ trace; however additional paleoseismic trenches northwest of the WM site could address this.

Based on geochronological results from geological units observed in the WM trench as well as subtle, yet continuous surface deformation along the fault, we infer that two Holocene earthquakes have deformed the surface along the northwest Meers fault and generated $\sim 0.8 \mathrm{~m}$ of northeast-side-up fold deformation per event. This does not account for the leftlateral component of per-event deformation, we find a preferred value of $1 \mathrm{~m}$ lateral slip based on a lateral- to vertical-slip ratio of 1.3:1 (Kelson and Swan, 1990; Swan et al., 1993). Taken together, the preferred full slip vector for these two Holocene earthquakes on the northwest Meers fault is $\sim 1.3 \mathrm{~m}$ per event. We did not find evidence for the youngest identified earthquake on the southeast section of the fault $(\sim 1200$ yr B.P.), indicating that the Meers fault may exhibit more complex rupture patterns than previously understood, where some surfacedeforming earthquakes do not rupture the entire length of the Holocene-active fault. We lengthen the mapped extent of the Holocene-active Meers fault to $\sim 43 \mathrm{~km}$, which supports the possibility of an $M_{\mathrm{w}} 7.0$ seismic event along the fault in the current stress field (Holland, 2013; Darold and Holland, 2015); this fault poses a significant seismic hazard for the CEUS.

\section{DATA AND RESOURCES}

We used light detection and ranging data collected by the Natural Resources Conservation Service (NRCS) and Federal Emergency Management Agency (FEMA) for this study from U.S. Geological Survey (USGS) 3D Elevation Program (3DEP) available at https:// nationalmap.gov/3DEP/ (last accessed December 2018). The USGS, Quaternary fault and fold database for the United States, 2006, from the USGS website is available at http//earthquakes.usgs.gov/hazards/ qfaults/ (last accessed September 2019). The C. Bronk Ramsey, OxCal ${ }^{14} \mathrm{C}$ calibration Program, v.4.3, Radiocarbon Accelerator Unit, University of Oxford, Oxford, United Kingdom, is available at https://c14.arch.ox.ac.uk/oxcal.html (last accessed November 2018). The supplemental material contains tables and figures including a mosaic of historic 1942 aerial photos along the northwest Meers fault, large-format high-resolution photomosaics and logs for the Water Moccasin trench, a stratigraphic column, and a table of detailed lithologic unit descriptions. Tables of OxCal model age results for the preferred and alternate age models, and OxCal codes for both models, are also included.

\section{ACKNOWLEDGMENTS}

The authors would like to thank Dean Reeder for granting them access to his property for mapping and paleoseismic excavations. Tom Cavenaugh excavated the Water Moccasin trench as well as additional trenches along the southeast Meers fault. The authors also would like to thank Tom for giving their team a flight in his airplane to view the fault, providing site access, and providing invaluable information about the historical land use along the Meers fault. The authors thank
Ramón Arrowsmith and Chris Crosby for their guidance and support of the authors' weather balloon structure from motion (SfM) mapping efforts. The authors thank Issac Woelfel, John Schwing, Noor Ghouse, and Stephen Holloway from the Oklahoma Geological Survey for their assistance in the field and logistical support. Reviews by Tony Crone, Angela Landgraf, and Nicola Litchfield and one anonymous reviewer greatly improved this article.

This research was supported by the U.S. Geological Survey (USGS), Department of the Interior, under USGS Award Number G16AP00142 to Portland State University, and G16AP00141 to the Oklahoma Geological Survey and Oklahoma University. Any use of trade, product, or firm names is for descriptive purposes only and does not imply endorsement by the U.S. Government. This work was also supported by a 2016 Geological Society of America Graduate Student Research Grant to K. Hornsby for field reconnaissance and SfM data collection.

\section{REFERENCES}

Baker, E. M., and A. A. Holland (2013). Probabilistic seismic hazard assessment of the Meers fault, southwestern Oklahoma: Modeling and uncertainties, Okla. Geol. Surv. Spec. Pub. SP2013-02.

Briggs, S. M., C. W. Fuller, K. I. Kelson, and J. Unruh (2008). The Criner fault in southern Oklahoma: Assessing seismic hazard in the central and southeast United States, Geol. Soc. Am. Abstr. Progr. 40, 16.

Bronk Ramsey, C. (2009). Dealing with outliers and offsets in radiocarbon dating, Radiocarbon 51, 1023-1045, doi: 10.1017/ s0033822200034093.

Bronk Ramsey, C. (2018). OxCal Program, v.4.3: Radiocarbon Accelerator Unit, University of Oxford, Oxford, United Kingdom, https://c14.arch.ox.ac.uk/oxcal.html (last accessed November 2018).

Caskey, S. (1995). Geometric relations of dip slip to a faulted ground surface: New nomograms for estimating components of fault displacement, J. Struct. Geol. 17, 1197-1202, doi: 10.1016/0191-8141 (95)00023-7.

Cetin, H. (1991). The northwest extension of the Meers fault in southwestern Oklahoma, Master's Thesis, Texas A\&M University, $84 \mathrm{pp}$.

Crone, A. J., and K. V. Luza (1990). Style and timing of Holocene surface faulting on the Meers fault, southwestern Oklahoma, Geol. Soc. Am. Bull. 102, 1-17, doi: 10.1130/0016-7606(1990) $102<0001$ :SATOHS $>2.3$. CO;2.

Crone, A. J., and R. L. Wheeler (2000). Data for Quaternary faults, liquefaction features, and possible tectonic features in the Central and Eastern United States, east of the rocky Mountain Front, U.S. Geol. Surv. Open-File Rept. 00-260, 342 pp., doi: 10.3133/ofr00260.

Darold, A., and A. Holland (2015). Preliminary Oklahoma optimal fault orientations, Okla. Geol. Surv. Open-File Rept. OF4-2015.

Gilbert, M. C. (1983a). The Meers fault of southwestern OklahomaEvidence for possible strong Quaternary seismicity in the midcontinent, Eos Trans. AGU 64, 313.

Gilbert, M. C. (1983b). The Meers fault-Unusual aspects and possible tectonic consequences, Geol. Soc. Am. Abstr. Progr. 18, 1.

Gray, H. J., S. A. Mahan, T. Rittenour, and M. Nelson (2015). Guide to luminescence dating techniques and their applications for paleoseismic research, in Basin and Range Province Seismic Hazards Summit III (BRPSHSIII), W. R. Lund (Editor), Utah Geological Survey 
Miscellaneous Publication 15-5, 19 pp., available at http://ugspub.nr .utah.gov/publications/misc_pubs/mp-15-5/mp-15-5_invited_paper. pdf (last accessed December 2018).

Hanson, R. E., R. E. Puckett, G. R. Keller, M. E. Brueseke, C. L. Bulen, S. A. Mertzman, and D. A. Mccleery (2013). Lithos intraplate magmatism related to opening of the southern Iapetus Ocean: Cambrian Wichita igneous province in the Southern Oklahoma rift zone, Lithos 174, 57-70, doi: 10.1016/j.lithos.2012.06.003.

Holland, A. (2013). Optimal fault orientations within Oklahoma, Seismol. Res. Lett. 84, 876-890, doi: 10.1785/0220120153.

Jones-Cecil, M. (1995). Structural controls of Holocene reactivation of the Meers fault, southwestern Oklahoma, from magnetic studies, Geol. Soc. Am. Bull. 107, 98, doi: 10.1130/0016-7606(1995) $107<0098$ :scohro $>2.3 . c 0 ; 2$.

Kelson, K. I., and F. H. Swan (1990). Paleoseismic history of the Meers fault, southwestern Oklahoma, and implications for evaluations of earthquake hazards in the central and eastern United States, in A. J. Weiss (Editor), Seventeenth Water Reactor Safety Information Meeting: Proceedings of the U.S. Nuclear Regulatory Commission NUREG/CP-0105, Vol. 2, 341-365.

Lienkaemper, J. J., and C. Bronk Ramsey (2009). OxCal: Versatile tool for developing paleoearthquake chronologies-A primer, Seismol. Res. Lett. 80, 431-434, doi: 10.1785/gssrl.80.3.431.

Luza, K. V., R. F. Madole, and A. J. Crone (1987). Investigation of the Meers fault in southwestern Oklahoma, Okla. Geol. Surv. Spec. Publ. 87-1, 75 pp.

Madole, R. F. (1988). Stratigraphic evidence of Holocene faulting in the mid-continent The Meers fault, southwestern Oklahoma, Geol. Soc. Am. Bull. 100, 392-401, doi: 10.1130/0016-7606(1988) 100<0392:SEOHFI $>2.3$.CO;2.

Perry, W. J. (1989). Tectonic Evolution of the Anadarko Basin region, Oklahoma, U.S. Geol. Surv. Bull. 1866-A, A1-A19, doi: 10.3133/ b1866A.

Prescott, J., and J. Hutton (1994). Cosmic ray contributions to dose rates for luminescence and ESR dating: Large depths and longterm time variations, Radiat. Meas. 23, 497-500.

Ramelli, A. R., and D. Slemmons (1990). Implications of the Meers fault on seismic potential in the central United States, in Neotectonics in Earthquake Evaluation, A. R. Ramelli and D. B. Slemmons (Editors), Geol. Soc. Am. Reviews in Engineering Geology, Vol. 8, 59-75, doi: 10.1130/REG8-p59.

Reimer, P. J., E. Bard, M. G. L. Baillie, A. Bayliss, J. W. Beck, P. G. Blackwell, C. Bronk Ramsey, C. E. Buck, H. Cheng, R. L. Edwards, et al. (2013). IntCal13 and Marine13 radiocarbon age calibration curves 0-50,000 years cal BP, Radiocarbon 55, 1869-1887.
Reitman, N. G., S. E. Bennett, R. D. Gold, R. W. Briggs, and C. B. DuRoss (2015). High-resolution trench photomosaics from imagebased modeling: Workflow and error analysis, Bull. Seismol. Soc. Am. 105, 2354-2366, doi: 10.1785/0120150041.

Scharer, K. M., R. J. Weldon, T. E. Fumal, and G. P. Biasi (2007). Paleoearthquakes on the southern San Andreas fault, Wrightwood, California, 3000 to 1500 B.C.: A new method for evaluating paleoseismic evidence and earthquake horizons, Bull. Seismol. Soc. Am. 97, 1054-1093, doi: 10.1785/0120060137.

Stanley, T. M., and G. W. Miller (2005). Geologic map of the Lawton $30^{\prime}$ X $60^{\prime}$ quadrangle, Caddo, Comanche, Cotton, Grady, Kiowa, Stephens, and Tillman Counties, Oklahoma, Oklahoma Geological Survey, Oklahoma Geologic Quadrangle OGQ-63, Scale 1:100,000.

Streig, A., and J. Chang (2018). Paleoseismic \& geophysical evaluations to improve seismogenic source characterization of the Meers fault, OK: Collaborative research between Geological Sciences, Portland State University and the Oklahoma Geological Survey, University of Oklahoma, U.S. Geological Survey National Earthquake Hazard Reduction Program Award Numbers G16AP00142 \& G16AP00141, U.S. Geological Survey Final Report, 31 pp., available at https:// earthquake.usgs.gov/cfusion/external_grants/reports/G16AP00141 .pdf (last accessed January 2019).

Stuiver, M., and H. A. Polach (1977). Discussion: Reporting of ${ }^{14} \mathrm{C}$ data, Radiocarbon 19, 355-363.

Swan, F. H., J. R. Wesling, K. A. Hanson, K. I. Kelson, and R. C. Perman (1993). Draft report-Investigation of the Quaternary structural and tectonic character of the Meers fault (southwestern Oklahoma), Technical Report to U.S. Nuclear Regulatory Commission, Washington, D.C., under Contract NRC-04-87-007, 104 pp., 3 pls.

U.S. Geological Survey (2006). Quaternary fault and fold database for the United States, USGS website, available at https:/earthquake .usgs.gov/hazards/qfaults/ (last accessed September 2019).

Walker, W. M. (2006). Structural analysis of the Criner Hills, SouthCentral Oklahoma, Master's Thesis, Baylor University, 64 pp.

Wells, D. L., and K. J. Coppersmith (1994). New empirical relationships among magnitude, rupture length, rupture width, rupture area, and surface displacement, Bull. Seismol. Soc. Am. 84, 9741002 .

Wheeler, R. L., and A. J. Crone (2001). Known and suggested Quaternary faulting in the midcontinent United States, Eng. Geol. 62, 51-78, doi: 10.1016/S0013-7952(01)00050-3.

Manuscript received 30 June 2018 Published online 10 December 2019 